H A R VARD D B U S I N E S S S C H O O L

\title{
Saving More to Borrow Less: Experimental Evidence from Access to Formal Savings Accounts in Chile
}

Felipe Kast

Dina Pomeranz

\section{Working Paper}

14-001

June 12, 2014 


\title{
Saving More to Borrow Less
}

\author{
Experimental Evidence from Access \\ to Formal Savings Accounts in Chile*
}

\author{
Felipe Kast $^{\dagger} \quad$ Dina Pomeranz $z^{\ddagger}$
}

June 2014

\begin{abstract}
Poverty is often characterized not only by low and unstable income, but also by heavy debt burdens. We find that reducing barriers to saving through access to free savings accounts decreases participants' short-term debt by about $20 \%$. In addition, participants who experience an economic shock have less need to reduce consumption, and subjective well-being improves significantly. Precautionary savings and credit therefore act as substitutes in providing self-insurance, and participants prefer borrowing less when a free formal savings account is available. Take-up patterns suggest that requests by others for participants to share their resources may be a key obstacle to saving.
\end{abstract}

JEL classification: D14, D91, G22, O16

\footnotetext{
*We are grateful to Fondo Esperanza, Banco Credichile and Microdatos for outstanding collaboration in the implementation process. We thank Ronald Abraham, Samuel Asher, Lorenzo Casaburi, David Clingingsmith, Shawn Cole, David Cutler, Edward Glaeser, Jessica Goldberg, Johannes Haushofer, Daniel Hojman, Lakshmi Iyer, Sarah Janzen, Sandy Jencks, Dean Karlan, Lawrence Katz, Jake Kendall, Michael Kremer, David Laibson, Dan Levy, Jeffrey Liebman, Stephan Meier, Sendhil Mullainathan, Karthik Muralidharan, Joana Naritomi, Oyebola Olabisi, Owen Ozier, Rohini Pande, Silvia Prina, Simon Quinn, David Roodman, Nicola Fuchs-Schuendeln, Russell Toth, Richard Zeckhauser and participants of various conferences and seminars for helpful comments and discussions. This project would not have been possible without the generous support by the following institutions: the Ford Foundation, the Lab for Economic Applications and Policy at Harvard University, the Women and Public Policy Program at the Harvard Kennedy School, the David Rockefeller Center for Latin American Studies, and the Russell Sage Foundation Small Grants Program. The experiment was carried out in accordance with Harvard GSAS IRB approval. Earlier versions of this paper circulated under the titles "Do Savings Constraints Lead to Indebtedness" and "Insurance through Savings Accounts."

${ }^{\dagger}$ Centro de Estudios Horizontal, fkast@horizontalchile.cl.

${ }^{\ddagger}$ Harvard University and NBER, dpomeranz@hbs.edu.
} 


\section{Introduction}

The lives of the poor are marked not only by low income, but also by frequent fluctuations and costly debt (Collins et al., 2009; Deaton, 1997; Barr, 2012; Banerjee and Duflo, 2007). The question of whether using debt is their preferred mechanism to deal with economic shocks arises. As many poverty-alleviation policies have focused on reducing credit constraints, concerns have increasingly been voiced about potential overborrowing by the poor (e.g. Roodman, 2012; Angelucci et al., 2013; Fafchamps, 2013; Schicks, 2013). We find that an oft-neglected aspect of financial exclusion, access to a formal savings account, can lead to reduced reliance on short-term debt and significant welfare improvements. Traditionally, the literature on consumption smoothing has focused on the opposite mechanism, in which credit constraints increase the precautionary savings motive (Deaton, 1991; Rosenzweig and Wolpin, 1993; Besley, 1995). The possibility to save in the form of a riskless bond or savings account is usually taken as given (e.g., Zame, 1993), since in contrast to borrowing from others, individuals do not need anyone elses money to save. An emerging literature shows, however, that individuals may not only be credit constrained, but also savings constrained, due to lack of access to formal savings accounts and problems of safety, self-control, and demands from others that limit the ability to save at home (e.g., Burgess and Pande, 2005; Ashraf et al., 2006b; Brune et al., 2011; Dupas and Robinson, 2013a,b). This issue is not limited to developing countries. Even in the United States, $8.2 \%$ of all households are unbanked (FDIC, 2011) and several government policies have aimed to improve access to bank accounts (Washington, 2006).

In a randomized field experiment among over 3,500 low-income members of a microfinance institution in Chile, we find that barriers to saving are binding enough to affect participants' borrowing behavior and welfare. Reducing barriers to savings through free and easy access to a formal savings account decreases participants' dependence on shortterm debt. The propensity to have loans with informal networks of friends and family, providers of basic services and utilities, business partners and money lenders is reduced. The total amount of outstanding short-term debt is reduced by about $20 \%$, mainly driven by the reduction in the outstanding debt to family and friends. Reducing the barriers to saving not only leads to a replacement of short-term debt by savings, but also improves overall consumption smoothing. Participants with access to a savings account have less need to reduce consumption when they experience an economic shock to their income. ${ }^{1}$

\footnotetext{
${ }^{1}$ The loans that the participants received from the microfinance institution were on a rigid schedule and
} 
The consumption cutbacks associated with a negative income shock are reduced by $44 \%$. The improvements correspond to the types of expenditures for which participants had expressed desire to build a buffer stock, and their magnitudes are in line with the 66,900 Chilean pesos (about 135 USD) in average deposits made by those who took up the account. These findings suggest that savings and credit are used as substitute inputs for consumption smoothing. As the cost of savings is reduced, demand for short-term credit decreases and overall consumption smoothing increases. In contrast, we find no effect on long-term debt such as mortgages or microfinance loans.

Participants experience substantial improvements in subjective well-being, both backward looking - they evaluate recent economic difficulties as less severe - and forward looking - they experience less anxiety about their financial future. The magnitudes of these improvements are large and correspond to more than half of the change in these well-being measures associated with a job loss or severe business downturn. This suggests that the original savings constraints alleviated by the intervention were substantial and costly for participants' well-being. Two specifically designed survey questions help us rule out that these subjective measures are driven by demand effects.

A formal savings account located away from the home potentially reduces both selfcontrol and "other-control problems." ${ }^{2}$ For half of the treatment group, self-control problems were additionally reduced through a commitment device based on self-help peer groups. In a separate study, we analyze this treatment, in which participants had the option to make a weekly deposit commitment and be held accountable by their peers (see Kast et al., 2013). Those who received this additional peer group support have significantly higher savings. This raises the question whether our findings are mainly driven by this subgroup. For most outcomes, this is not the case. Despite limited statistical power when analyzing differential impacts between the two sub-treatments, the reduction in the propensity to borrow and the improved consumption smoothing for those with an income shock remain significant also among those who only received the basic savings account. The one outcome for which there is a significantly stronger effect for those with the additional peer group support is the forward-looking measure of anxiety about the financial future, consistent with the larger buffer stock accumulated by these participants.

could therefore not be used for unexpected shocks. In focus groups prior to the intervention, participants expressed strong desire to increase precautionary savings for such occasions.

2 "Other-control" problems can result when individuals feel pressured to share their resources with members of the family and the community (e.g., Hertzberg, 2010; Brune et al., 2011). 
The take-up patterns of who opens and uses the account are also informative about what the obstacles to savings might have been prior to the intervention. They suggest that other-control problems are a significant constraint. Take-up of the account is particularly high among participants who are not the head of their household, who have conflicts with their partner over money, and (in line with Dupas and Robinson, 2013b) those who are "socially taxed" through their social network, i.e. those who are lending to others and are not borrowing from their network themselves. In line with this, those who regretted not having saved more before the intervention reduce their lending to others as a result of having access to the savings account. Consistent with Ashraf et al. (2006b), take-up is also substantially higher for those with hyperbolic time preferences, which may lead to both increased self and other-control problems.

This paper makes contributions to the literature on savings in several ways. First, our findings provide what is, to our knowledge, the first micro-empirical evidence that reducing barriers to savings reduces the reliance on debt. As mentioned above, the literature on precautionary savings has long acknowledged that saving and borrowing are two substitute mechanisms to help individuals smooth consumption in the face of shocks. In principle, credit is simply a form of negative savings. Typically, it has been assumed that the constraint in this substitutive relationship lies on the credit side, and that if individuals are credit constrained, they have more of a need to build a buffer stock for self-insurance. ${ }^{3}$ On the other hand, even if individuals have the ability to borrow, they might prefer to save, depending on their level of risk aversion and the cost of savings. ${ }^{4}$ We test whether the limited accessibility of formal savings accounts leads to savings constraints that are binding enough to push participants to borrow more than they otherwise would and to affect participants' economic well-being. As in many low-income contexts (e.g., Townsend, 1994; La Ferrara, 2003; Lusardi et al., 2011; Kinnan and Townsend, 2012; Mazzocco and Saini, 2012), participants in our population often resort to informal credit from their network of family and friends and other sources of short-term debt to help smooth consumption. ${ }^{5}$ When participants gain access to the free savings accounts they

\footnotetext{
${ }^{3}$ The use of buffer stocks for self-insurance has been shown empirically by, e.g., Paxson (1992), Udry (1995) and Alderman (1996), who show how people use savings in response to income shocks. For an overview on savings motives and precautionary savings see Browning and Lusardi (1996).

${ }^{4}$ In addition to the forgone consumption, the costs of saving also include costly features of formal savings accounts, as well as costs associated with saving at home, including fear of theft, self-control problems to refrain from spending cash on hand, or other-control problems to resist demands from others to share these resources with them.

${ }^{5} \mathrm{~A}$ number of studies have analyzed the degree to which individuals are able to smooth shocks through these methods and find that even though social networks can play an important role, they often do not
} 
not only substitute towards precautionary savings, but also choose to increase overall levels of smoothing. Even though building a buffer stock requires reducing consumption in the short-run, participants prefer this form of smoothing to the measures that they were using beforehand, suggesting that these measures were relatively costly.

Second, our findings contribute to a rapidly growing literature showing benefits of facilitating savings on a variety of outcomes such as poverty reduction (Burgess and Pande, 2005), investment and income (Brune et al., 2011; Dupas and Robinson, 2013a; Prina, 2013), and female intra-household bargaining power (Ashraf et al., 2010). This paper provides what is, to our knowledge, the first direct evidence showing that access to a fully liquid savings account can help individuals improve consumption smoothing in the face of economic shocks. This growing body of research showing positive effects of savings indicates that mechanisms aimed at helping individuals increase their savings (such as studied by Ashraf et al., 2006a,b; Brune et al., 2011; Schaner, 2011; Kast et al., 2013; Atkinson et al., 2013; Dupas and Robinson, 2013b) can be very beneficial. At the same time, several of the commitment devices that have been found to help individuals in developing countries increase their savings are withdrawal commitment devices which limit the liquidity of the accounts. In order for the savings to serve a precautionary purpose, liquidity is important. As discussed in more detail in the conclusion, our results suggest that a trade-off may exist between the benefits of withdrawal commitment devices and the ability to use savings for consumption smoothing.

Third, our findings add to the literature on the relationship between poverty and subjective well-being measures. They suggest that in addition to the importance of levels of income and poverty for subjective well-being, their variance and the risk to which people are exposed may play an important role. The poor often experience great worry and anxiety about their economic future (e.g., Collins et al., 2009; Haushofer et al., 2012), and a growing literature studies the impact of interventions aimed at reducing poverty and its consequences on psychological and subjective well-being (e.g., Cattaneo et al., 2009; Devoto et al., 2012; Ludwig et al., 2012). While such worry is an important issue to address in itself, it can also have negative feedback effects on economic decision-making, and potentially lead to a poverty trap (Shah et al., 2012). At low levels of income, mechanisms to smooth consumption are particularly important since economic shocks can have devas-

provide full insurance (e.g., Townsend, 1994; Morduch, 1995; Ligon et al., 2002; Kinnan and Townsend, 2012). Jack and Suri (2014) find that the introduction of mobile money through cellphones can strongly increase the degree of such insurance by facilitating redistribution across geographic locations where shocks are less correlated. 
tating effects and lead resources to fall below what is required to cover basic needs (e.g., Townsend, 1994; Morduch, 1995). At the same time, the poor are often faced with highly variable income streams and expenditure shocks (e.g., Townsend, 1995; Deaton, 1997; Fafchamps and Lund, 2003; Banerjee and Duflo, 2007; Munshi and Rosenzweig, 2009) and have limited formal insurance (e.g., Jacoby and Skoufias, 1997; Banerjee and Duflo, 2007; Giné and Yang, 2009; Cai et al., 2012; Giné et al., 2012; Cole et al., 2013b). Being dependent on the social network for insurance can also be psychologically or practically costly (Dezső and Loewenstein, 2012; Jakiela and Ozier, 2012). All of these factors may contribute to our finding of large improvements in participants' assessment of their recent economic difficulties and their anxiety about their financial future. More research is required to study the relative importance of levels of income and poverty, versus their variance, in affecting psychological health and subjective well-being.

Finally, this paper provides evidence for a growing body of research showing that the ability to save interacts with the relationships individuals have in their social network. This interaction can play out in two directions with the social network can affecting savings, and vice versa. In the first direction, peers and the social environment can make it either harder for individuals to save (due, for example, to pressure to share resources, as in Baland et al., 2011; Brune et al., 2011; Schaner, 2013) or easier (for example as a commitment device, as in Kast et al., 2013). At the same time, access to savings can in turn affect participants' financial relationship to others in their social network (Flory, 2012; Comola and Prina, 2013). We find evidence for both directions. Participants who are subject to more other-control problems are more likely to take up the account, and access to the account in turn reduces lending to others among those who initially regretted not having saved more. When thinking about different savings policies, it is therefore important to also consider their possible interactions with the social environment.

The remainder of the paper is organized as follows: Section 2 provides information about the background, data and study design, Section 3 discusses results, robustness checks, and determinants of take-up and Section 4 concludes. 


\section{Background, Data and Study Design}

\subsection{Background and Data}

The study was conducted in collaboration with Fondo Esperanza (FE), a Chilean microfinance institution, and Banco Credichile (BC), a large commercial bank. The savings accounts that were offered to FE's members as part of the intervention were held with Banco Credichile because FE is not legally licensed to hold savings deposits. FE's members are self-employed micro-entrepreneurs (e.g., street vendors or cosmetics saleswomen), many of whom work in the informal sector. About $91 \%$ are women, and most live and work in urban areas. FE provides micro-loans to its members in three-month cycles, repayment of which is monitored in weekly or biweekly group meetings.

FE's credit disbursement and repayment is on a very rigid schedule, and consequently cannot be used as insurance for emergencies or for unexpected income or expenditure shocks, similar to other micro-credit arrangements (Karlan and Mullainathan, 2010). ${ }^{6}$ Given the rigidity in the timing of the loans, it is not surprising that in focus groups conducted prior to the intervention, many members expressed the desire to increase their liquid savings to build a buffer stock for unexpected shocks and emergencies. ${ }^{7}$ Participants emphasized several constraints to their current ability to save. First, monetary costs were a major constraint and participants mentioned the need for cost-free accounts. Due to the fee structure of the accounts that were generally available at that time, accounts with small balances often faced potentially large negative returns. The concern with the fixed costs of formal savings is in line with findings by Cole et al. (2011) in Indonesia and Dupas et al. (2012) in Western Kenya. In addition to the financial costs, mental transaction costs also seemed to contribute to the savings constraints. Many expressed concerns about feeling intimidated to go into a bank or not knowing what would be required to be eligible to open an account.

This population is of particular interest to study since it has sometimes been questioned whether microcredit makes participants borrow too much, and whether it might be in their interest to build up savings instead, in order to reduce the need for credit (e.g., Ananth et al., 2007). It is therefore of interest to study whether increasing access

\footnotetext{
${ }^{6}$ Field et al. (2012) show that relaxing this rigidity, and in particular, delaying the time when the loan repayment starts, can increase business investment and profits.

${ }^{7}$ None of the participants of the focus groups were subsequently included in the randomized study, to avoid any possible contamination of the study by the pre-treatment discussions.
} 
to a formal savings vehicle reduces borrowing. If participants continue borrowing, large amounts of savings would be suboptimal, as they continue paying expensive interest rates that they could reduce by paying down the debt. However, some amount of precautionary savings is valuable at any level of debt because of the difference in liquidity of savings and loans (Zinman, 2007). If the debt cannot be taken out flexibly, then having a small savings cushion for emergencies can make an important difference in reducing the pressure of economic fluctuations. This is particularly the case for a population such as the participants in this study, who work predominantly in the informal sector and experience frequent income and expenditure shocks.

This study draws on three different sources of data. All outcome variables, as well as most personal characteristics, were obtained through extensive baseline and followup surveys. The baseline survey was conducted prior to the introduction of the savings accounts in April-May 2008 during one of the group meetings. The follow-up survey was administered in June-July 2009 at the participants' home or work place so that those who had left FE in the meantime could still be reached. The surveys include detailed questions about participants' savings and debt, their economic situation, recent consumption patterns, as well as subjective measures such as participants' anxiety about their financial future, assessment of their recent economic difficulties, regret about not having saved more, and time preferences.

The questionnaires were administered by the independent survey agency, Centro de Microdatos at the University of Chile. While participants were aware that the survey was related to their membership with $\mathrm{FE}$, they had no way of knowing that it was related to the savings accounts offered by BC. As discussed below in Section 3.3, the survey also included two questions specifically designed to test for demand effects to rule out the possibility that receiving access to a savings account through FE affects participants' propensity to respond to survey questions in a favorable or socially expected way.

We complement this survey data with two sources of administrative records. Information on savings in the study accounts was obtained directly from BC. Finally, we used FE's administrative files to obtain information on each participant's estimated household size, household income, and years of education. 


\subsection{Balance of Randomization and Baseline Summary Statistics}

Table 1 presents baseline summary statistics. Columns (1) and (2) show that in the overall sample, characteristics in the treatment group are not statistically significantly different from the control group. Participants are on average 43 years old and have 10 years of schooling. The average household size is 4.3 and the mean monthly income per capita in the household is 80 thousand Chilean pesos (about 160 USD), with a median of 66 thousand. ${ }^{8}$ Sixty eight percent of participants did not have a savings account prior to the study. Correspondingly, the median amount of pre-existing formal savings in a bank or a cooperative is zero, with a mean of 63 thousand pesos. While income is reported in per capita terms, these figures may represent the savings of several household members combined, especially those of participants' children.

[Table 1]

Participants' short-term borrowing and lending behavior is captured by two types of measures. The first is the amount of short-term lending and borrowing. The second measure is less noisy and captures the extensive margin of categories of people and institutions that participants have borrowed from or lent to, such as parents, neighbors, business partners etc. Table 1 shows that participants had an average of 166 thousand pesos in outstanding short-term debt (66 thousand when winsorized at the 95th percentile) and owed money to an average of 0.91 of the 15 possible categories of short-term creditors. The average amount of lending was 110 thousand pesos (69 thousand when winsorized at the 95th percentile) and this was lent to an average of 1.07 of 9 possible categories.

To measure consumption smoothing, we develop a new approach. Rather than eliciting detailed consumption data, which is complex to capture and often provides quite noisy measures, we asked participants directly whether they had to cut back consumption on a series of specific items due to economic difficulties in the preceding three months. ${ }^{9}$ This approach follows the same logic as De Mel et al. (2009), who find that small business owners are capable of reporting their overall profits directly with just as much or better accuracy than surveys that elicit detailed cost and revenue data. In our sample, $70 \%$ of participants reported having had to reduce at least one of the consumption items. We

\footnotetext{
${ }^{8} 500$ Chilean pesos $=$ approximately 1 USD.

${ }^{9}$ The consumption items include meals, meat, medicine, school supplies, clothing, school snacks, walking instead of using public transportation, and eating out. These items resulted from the cutbacks mentioned by other FE members in focus groups conducted prior to the intervention.
} 
validate this new measure by testing whether it correlates in the predicted way with participants' personal economic situation. Indeed, we find that those who experienced a job loss in the household or a significant downturn of their business in the preceding three months reported cutting back consumption in 53\% more categories than those who did not.

While this measure captures only the variance of consumption, rather than the level, it has several advantages compared to alternative approaches that measure overall consumption and then back out consumption cutbacks from there. It does not require participants to recall the specific amounts consumed, which can be quite unreliable (Ahmed et al., 2006), nor to fill out detailed consumption diaries. This allows the survey to be shorter, thereby increasing the quality of response on other sections of the survey, as participants are less fatigued (see e.g. Herzog and Bachman, 1981; Galesic and Bosnjak, 2009). At the same time, it also avoids any potential direct effects of keeping a consumption diary on the behavior or perception of participants (for examples of such effects see e.g. Deaton, 1997 and Zwane et al., 2011).

With respect to measures of self-reported well-being, the survey includes one forwardlooking and one backward-looking question. The forward-looking question asked participants if they were anxious about their financial future. The mean response was 2.9 on a scale of 1 to 4 , where 1 means strongly agree and 4 means strongly disagree. The backward-looking measure was asked after the specific questions about participants' recent economic shocks, consumption etc. in order to allow participants to recall and evaluate their recent economic situation more accurately. The question on recent economic difficulties asks, "In sum, thinking about all the economic difficulties of the last three months, on a scale of one to ten, how difficult was this situation for you?" The mean answer was 5.1 on a range of 1 to 10 .

In the follow-up survey, conducted one year after the introduction of the accounts, 592 (14.2 percent) of the original 4,175 participants from the baseline could not be found by the survey agency. For these participants, no outcome variables are available, and they could therefore not be included in the impact evaluation. All final outcomes reported in this paper therefore exclude these 592 individuals. Columns (3) and (4) of Table 1 show the baseline summary statistics for this sample. Similar to the full sample, none of the characteristics are significantly different between the treatment and control groups. Section 3.3 discusses the attrition in more detail and provides robustness checks to address it. 


\subsection{Implementation and Empirical Specification}

Prior to any intervention, the baseline survey was conducted among 307 groups of Fondo Esperanza's (FE's) members. The universe of study participants consists of all members who were present in the meeting when the baseline survey was administered. Two-thirds of the groups were randomly selected to be offered a free savings account while the control group was not eligible for this type of savings account. The randomization was conducted at the group level. All members of each group received the same treatment, such that participants in the control group were not affected indirectly by the treatment through spillover effects within the FE group.

The opportunity to open a savings account was introduced during group meetings in the weeks following the baseline survey. The accounts were set up in a way to minimize both financial and mental transaction costs. In contrast to other savings accounts available in the market at the time, the study accounts had no maintenance fees and no minimum balance. The minimum opening deposit was only 1,000 Chilean pesos (about 2 USD). Take-up of the account was completely voluntary. In order to overcome the frequently expressed sentiment of feeling intimidated to enter a bank, interested participants were offered an opportunity to go to the bank together with their peers to open an account and were informed precisely which documents were required to open the account. ${ }^{10}$ Savings in the accounts were fully liquid for withdrawal at the bank's branches at any time.

The standard accounts had a standard real interest rate of $0.3 \%$. A subgroup of one quarter of treated groups was randomly assigned to receive a preferential interest rate of $5 \%$, and in half of the treated groups, self-control problems were additionally reduced through a peer group commitment mechanism. These conditions were guaranteed for a minimum of two years. Kast et al. (2013) study the differential savings behavior resulting from these different sub-treatments. ${ }^{11}$ The $5 \%$ interest rate did not affect savings for the vast majority of participants, while the peer group commitment device significantly increased the number of deposits and almost doubled the average balance in the accounts. Section 3.3 therefore analyzes whether there are differential effects for those who had additional support through the peer group deposit commitment device. The main analysis

\footnotetext{
${ }^{10}$ In the baseline survey, $46 \%$ the of participants reported that they did not like entering a bank because they felt intimidated.

${ }^{11}$ Another intervention studied in Kast et al. (2013), in which feedback messages were sent to participants, was launched only after the follow-up survey and does therefore not affect the results presented in this paper.
} 
of the paper focuses on the overall impact of reducing barriers to saving through access to any of the savings accounts.

To analyze the effect of having a savings account on various outcomes of interest, we estimate a simple difference-in-difference specification, comparing those in the treatment group to those in the control group at the time of the baseline and follow-up survey:

$$
Y_{i t}=\alpha+\beta \text { AccountAccess } s_{i t}+\gamma_{i}+\delta_{t}+\epsilon_{i t},
$$

where $Y_{i t}$ is the outcome variable of interest, AccountAccess $s_{i t}$ is a dummy variable that takes on the value one if individual $i$ is in the treatment group and period $t$ is the treatment period. Individual fixed effects are represented by $\gamma_{i}$, time fixed effects by $\delta_{t}$, and $\epsilon_{i t}$ is the error term. All standard errors are clustered at the group level.

This analysis provides the Intent-to-Treat (ITT) effects of the intervention. We do not calculate the Treatment-on-the-Treated (TOT) effects, since opening an account can have potential spillover effects on other members of the group who do not take up the account. The ITT specification incorporates such potential spillover effects. Assuming spillovers are zero and given that the take-up rate is $39 \%$, the TOT effect would be a little under triple the size of the ITT effect.

To capture participants' short-term borrowing and lending behavior, we asked them a series of detailed survey questions on whether they had lent to or borrowed from a particular category of person or institution (such as a parent, neighbor, supplier, etc.) and if so how much. These categories fall into one of five forms of debt or lending: (1) informal borrowing from family and friends, (2) outstanding payments to service providers and utilities, (3) debt to business contacts and short-term lending institutions, (4) lending to family and friends, and (5) lending to business contacts. ${ }^{12}$ As outcome variables we use both the amounts of debt or credit and the number of categories of debt or credit that participants had.

Many topics in our analysis are addressed by a series of related questions (e.g. cut-

\footnotetext{
${ }^{12}$ The categories in each of these five forms are as follows. (1) \& (4) Borrowing from and lending to friends and family: parents, children, siblings, partner, friends, and other relatives. (2) Debt to service providers: medical facilities, educational institutions, and utilities (water, gas, electricity, phone). (3) Debt to business contacts and short-term lending institutions: suppliers, business partners, stores, nonbank lending institutions (so called financieras and cooperativas), and money lenders. The variable does not include long-term financial debt, such as mortgages, formal bank loans, promissory notes and loans with FE, which cannot be used for quick emergency borrowing. (5) Finally, lending to business contacts: clients, business partners, and FE partners.
} 
back of a number of consumption items, forward-looking and backward-looking subjective wellbeing, etc.). To assess the overall statistical significance of such related outcome variables, we also report the average effect size (AES), using the methodology in Kling et al. (2004) and Clingingsmith et al. (2009). The AES of each grouping of outcome variables serves as an index of the underlying individual treatment effects. It is calculated using the average of the normalized treatment effects from each of the underlying regressions. ${ }^{13}$ Looking at the overall AES reduces the risk of falsely accepting individual treatment effects that are significant only by chance.

\section{Results}

\subsection{Impact of Access to a Savings Account}

\section{Account Usage}

Take-up of the account was voluntary. $53 \%$ of eligible participants opened an account and $39 \%$ actively used it. An active user is defined as someone who deposited more than the 1,000 pesos minimum opening amount. Following Dupas et al. (2012), we use active use as our take-up measure. Section 3.2 discusses determinants of take-up and what they suggest about underlying barriers to saving. For those who actively used the account, the mean number of deposits over the course of a year was 4.4 and the median was 2 . They deposited an average of 66,900 pesos in total (about 135 USD) with a median of 9,000 pesos. The average number of withdrawals was 1.0 and the total amount withdrawn was 46,700 (about 95 USD) on average. Over the year of the study, participants held an average monthly savings balance of around 18,500 Chilean pesos (about 37 USD). This balance amount represents about $23 \%$ of monthly income and corresponds in size to the type of expenditures for which participants had expressed wanting to build a buffer, such as unexpected doctor's visits and payments for heating, electricity or food during periods of short-term income fluctuation.

[Table 2]

\section{Borrowing}

\footnotetext{
${ }^{13}$ Since the AES cannot deal with large numbers of fixed effects, we include a treatment dummy in the AES regressions in place of the individual fixed effects.
} 
We first analyze the impact of access to a savings account on the use of short-term credit. If savings were to have a precautionary purpose, as participants had stated in the focus groups, having more savings could reduce the need for short-term debt to cope with economic fluctuations.

[Table 3]

Panel A in Table 3 shows that indeed, the amount of outstanding short-term debt declines by 12,931 pesos for those with access to the account, significant at the $5 \%$ level. ${ }^{14}$ This represents a reduction of $20 \%$ compared to the post-intervention mean in the control group. Looking at what type of short-term debt is reduced, we see the strongest reduction on the amount owed to family and friends with 6,500 peso, significant at the $1 \%$ level. This represents a $38 \%$ reduction compared to the post-intervention control group mean. Within family and friends, the reduction is strongest for parents, significant at the $1 \%$ level, who are the most frequent category participants borrowed from within family and friends.

Next, we look at an alternative, less noisy measure: the discrete number of categories of people or institutions with which participants reported having any debt, such as parents, siblings, neighbors, or suppliers. Panel B shows a reduction of 0.127 categories, significant at the $5 \%$ level, for those with access to the account. This represents a decrease of $22 \%$ compared to the control group mean in the post-treatment period.

Looking at the three types of borrowing we see that the largest decrease again stems from informal borrowing from family and friends, which is reduced by 0.072 , significant at the $5 \%$ level. This is a $36 \%$ decrease compared to the control group mean in the post-treatment period. Among the specific categories, borrowing from parents was again reduced the most, significant at the $1 \%$ level. With this discrete measure of borrowing, the outstanding payments to service providers also decline significantly, by 0.057 categories, significant at the $5 \%$ level, representing a reduction of $24 \%$ compared to the control group mean in the post-treatment period. Within the components of outstanding payments, the reduction in debt with utility providers (electric, gas, water, and telephone) is the largest with $37 \%$, significant at the $5 \%$ level. Outstanding payments to utility providers can have particularly negative effects, as they can lead to participants' families being left without heating or electricity until payment is restored.

\footnotetext{
${ }^{14}$ These results are winsorized at the 95 th percentile due to large outliers. See Appendix Table A1 for unwinsorized amounts.
} 
There is again no significant effect on the overall debt to business contacts and nonbank lending institutions. Among the components of this form of borrowing, the probabilities of borrowing from money lenders and from business partners were significantly reduced at the $5 \%$ level. However, since both of these types of borrowing are not frequent, they do not significantly affect the overall number of categories.

To confirm that the decrease in borrowing is indeed concentrated on short-term debt that serves to smooth economic shocks or emergencies, we also look at long-term borrowing in the form of mortgages, loans with FE, formal bank loans, etc. Consistent with the role of savings as a substitute for borrowing for self-insurance, we find no impact on long-term borrowing amounts or categories.

Since credit is expensive, one could imagine that participants use their savings account to build savings not only towards a buffer stock for self-insurance but also to reduce their next installment of micro-credit for their business investments, or to pay down longterm debt. The fact that we do not find evidence for this suggests that building a buffer stock might be more urgent for this population than reducing debt. It is also consistent with the notion that participants do not want to discontinue their micro-credit since participating with FE provides them with other benefits. Whether or not it is beneficial for this population to use micro-credit is a separate question that is beyond the scope of this paper. It is nevertheless interesting to note that participants seem to reduce borrowing from family and friends before reducing borrowing from the MFI.

\section{Lending}

Having established the reduction in short-term borrowing, we look at the other dimension of debt, i.e. being a creditor. Having a savings account could lead participants to become less generous in providing loans to their social network, since they now depend less on loans from their network for insurance purposes. In addition, savings accounts may allow individuals to shield their savings from requests of others to share. On the other hand, having a buffer stock may allow individuals to help their social network with a loan in times of need. The evidence on this issue is quite mixed. Chandrasekhar et al. (2012) find no negative impact of access to savings on interpersonal transfers in a lab experiment in India. Flory (2012) finds in Malawi that having a savings account increases participants' cash gifts to others.

[Table 4] 
Table 4 displays the impact on lending to others. For the full sample (Columns 1-3), there are no statistically significant effects on amounts lent or categories of borrowers lent to. However, for the $68 \%$ who indicated in the baseline survey that they always or frequently regret not having saved more (Columns 4-6), there is a significant reduction in lending both in amounts (12 thousand pesos) and in categories of borrowers (0.61 categories). ${ }^{15}$ For both amounts and categories, the effect is largest on lending to family and friends, significant at the $1 \%$ level. In addition, the reduction for business contacts is also marginally significant.

This finding is consistent with the notion of other-control problems, i.e. the requests for money by others may have presented an obstacle to building their own savings for this group, which led them to regret not having saved more. Once they have a place to store their savings away from home, they are able to reduce their loans to others and build their own buffer stock of savings. As we will see in Section 3.2 below, this interpretation is also consistent with the take-up pattern. However, since we did not start the analysis with a hypothesis for the subgroup that regretted not having saved more in mind, further research is required to investigate whether this differential effect is robust to replication.

\section{Consumption Smoothing}

The preceding results showed that participants substitute credit with savings and significantly reduce their use of short-term borrowing when given access to a savings account. If savings and credit are substitute mechanisms for consumption smoothing, the question arises of whether relaxing the savings constraint mainly leads to a replacement of credit by savings, or whether overall smoothing is increased in addition. It is conceivable that participants' main response to access to the savings accounts is to substitute to a different means of smoothing, while maintaining their overall level of smoothing. This section analyzes how the intervention affects participants' ability to smooth consumption during times of economic shocks to their income.

As discussed in Section 2.2 above, our measure of consumption smoothing asks participants directly, whether they had to cut back various forms of consumption due to hard times in the preceding three months. Overall in this population, the need to reduce consumption due to economic difficulty is quite frequent. In the baseline, $70 \%$ of participants reported having to cut back on at least one of the consumption items in the pre-treatment

\footnotetext{
${ }^{15}$ The amounts are again winsorized at the 95 th percentile due to large outliers. See Appendix Table A2 for the non-winsorized amounts.
} 
period. For the individual items, this frequency ranges from $8 \%$ to 51\%, with the largest proportion of participants reducing clothing, eating out and meat consumption. To establish which participants were affected by a shock to their income, we asked whether they had experienced a job loss in the household or a significant business downturn. Forty percent of participants experienced at least one such shock in the three months preceding the follow-up survey. Table 5 shows how their need to reduce consumption due to hard times was affected by the treatment.

\section{[Table 5]}

First, the coefficients on the post-treatment dummy indicate that indeed, those who experienced a recent shock had to increase the extent to which they had to cut back consumption on many of the specific items. This increase is offset by more than half for those who had access to the savings account. The effect is particularly large for meat and walking instead of using public transportation. ${ }^{16}$ While the cutback is not statistically significant for many of the individual coeffecients, the relevant question for the analysis is whether there has been an overall reduction. Indeed, we find that the relatively small buffer stock amounts seem to have a significant impact in helping participants cope with income fluctuations. The overall AES for reduction in consumption cutbacks of -0.112 is significant at the $5 \%$ level. ${ }^{17}$

Quantitatively, these effects are substantial. Using a triple difference specification, we find that for participants who were offered an account, the overall increase in consumption cutbacks associated with an income shock (measured as the number of items for which consumption had to be reduced) was mitigated by $44 \%$. In the treatment group, a negative income shock in the post-treatment period was associated with a 0.49 increase in cutbacks, compared to a 0.88 increase in the control group ( $\mathrm{p}$-value of the difference $=0.059) .{ }^{18}$ These findings show that access to the savings accounts helped participants better smooth their consumption following an income shock.

\footnotetext{
${ }^{16}$ Specifically, in the urban Chilean context, the poor's workplace is often far away from their home, with business activities located in the city center and housing for the poor at the outskirts. Cutting back on public transportation in these cases therefore often means a walk of two or more hours in each direction.

${ }^{17}$ Table A3 in the Appendix shows consumption cutbacks for the full population, including those who did not experience a shock. Again, the frequency of reducing consumption is reduced for almost all items, however, the overall impact is no longer statistically significant (AES p-value $=0.23$ ).

${ }^{18}$ These estimates result from a triple difference-in-difference regression that compares the impact of an income shock in the post-treatment period on participants' consumption cutbacks between those who were and were not offered an account, controlling for time period and individual fixed effects.
} 


\section{Subjective Well-Being}

Both the reduced indebtedness and the improved consumption smoothing capability can potentially contribute to alleviating participants' perceived economic well-being and anxiety about their financial future. Beyond the physical challenges of limited consumption, worry and anxiety about one's economic situation is one of the difficult characteristics that mark the lives of many of the poor. Qualitative and correlational evidence suggests that debt can be a particular source of such mental distress (e.g. Taylor et al., 2006; Kuruvilla and Jacob, 2007).

We assess whether participants experienced a subjective insurance effect from access to the savings account through one forward- and one backward-looking measure: participants' anxiety about their financial future and their overall assessment of recent economic difficulties (see Section 2.2 for a more detailed description of these variables). Table 6 shows the impact on both of these outcomes. Since the units of measurement for anxiety and economic difficulty are not quantitatively meaningful, we normalize them to have a mean of zero and a standard deviation of one among the control group. This way, the effects are expressed in terms of standard deviations. One year after receiving a savings account, participants in the treatment group are 0.112 standard deviations less anxious about their financial future than those in the control group and experience their overall recent economic situation as 0.087 standard deviations less difficult. The overall AES on subjective well-being is -0.102 and significant at the $5 \%$ level.

[Table 6]

To facilitate the interpretation of the magnitude of these treatment effects, we compare them to changes in these measures associated with other economic events, such as a job loss in the household and a significant business downturn. ${ }^{19}$ This benchmark comparison reveals that the effects are substantial. The magnitude of the backward-looking effect of access to the account on perceived recent economic difficulties is $78 \%$ as large as the change of this measure associated with a job loss in the household and $54 \%$ as large as the change associated with a business downturn. The forward-looking effect of access to the savings account on participants' anxiety about their financial future is $117 \%$ as large

\footnotetext{
${ }^{19}$ To measure this association, we compare the coefficients in Table 6 to the change associated with having experienced an economic shock in the preceding three months, as captured by a difference-indifference regression of job loss or business downturn in the preceding three months on the two subjective well-being measures respectively.
} 
as the change in anxiety associated with a job loss, and $57 \%$ as large as the change associated with a business downturn. In sum, as a rough benchmark comparison, receiving access to the savings account improves subjective well-being by more than half as much as not losing a job or experiencing a business downturn - a quite sizeable amount.

We can further examine the improvements on the self-reported well-being measures through generalized ordered probit estimation. This allows us to see where in the distribution the improvements are coming from. Tables A4 and A5 in the Appendix show the results for anxiety and perceived recent economic difficulties, respectively. In Table A4, Column (3) shows that the improvement in anxiety is particularly strong at the top of the distribution, making participants significantly less likely to stay in the most anxious category. With respect to the rating of recent economic difficulties (Table A5), the impact seems to be strongest in the middle of the distribution. For both subjective well-being measures, the coefficients point towards improvement throughout the whole range of the distribution.

Overall, the analysis of the impact on subjective well-being reveals sizeable improvements in both participants' assessments of their recent economic situation, and in their outlook of the future.

\section{Other Outcomes}

There are two groups of outcome variables that we tested, but for which we do not find statistically significant effects - household dynamics and spending on bulky purchases. Money is often a major source of conflict among couples, and in other contexts, savings outside of the house have been found to play an important role as a strategy for women to hide money from their husbands (Anderson and Baland (2002), looking at ROSCAs in Kenya) or as a means for women to improve bargaining power and control over their spending decisions (Ashraf, Karlan and Yin (2010) in the Philippines; Dupas and Robinson (2013a) in Kenya). Our results, however, find no significant effect on household dynamics. ${ }^{20}$ One reason why access to a savings account does not lead to a change in the intra-household dynamics in our study might be that in Chile, women are traditionally in charge of household finances and savings decisions, so the introduction of the savings accounts may not have a significant impact on these power dynamics.

\footnotetext{
${ }^{20}$ The questions in this module were: Who in the household makes decisions about spending? Who in the household makes decisions about savings? Do you hide savings from your partner or other relatives? Did you recently ask your partner for money? Do you have conflicts with your partner about money?
} 
We also find no effects on bulky expenditures. The sub-questions in this category ask whether in the previous three months, participants made purchases in any of the following categories: (1) a television, radio, or computer; (2) machinery or equipment for their business; (3) making significant improvements in their home (painting, floor, roof, etc.); (4) paying down their debt to FE in advance. While the lack of effect on these bulky items might simply mean that the survey did not include the relevant items, it is consistent with the interpretation that participants mainly used their liquid savings accounts to build a buffer stock for insurance, and reserved their chunky credit with FE for bulky expenditures and investments.

\subsection{Take-up}

The take-up patterns for the accounts provide interesting insights into the drivers of demand for the formal savings accounts, and suggestive results as to what the underlying savings constraints without an account may be. In Table 7, Panel A shows demographic determinants of take-up and Panel B analyzes other personal characteristics that may affect savings decisions, controlling for the demographics in Panel A. The personal characteristics that are predictive of take-up are consistent with a situation where participants use the account in order to reduce both their self-control and other-control problems.

[Table 7]

Household dynamics that are indicative of other-control problems are predictive of take-up. Being head of the household - an indicator of having more control over intrahousehold resource allocation - is negatively correlated with take-up. For heads of household, take-up is 4 percentage points lower, a reduction of 10 percent compared to the overall take-up rate, and is significant at the $10 \%$ level (controlling for demographic variables and other personal characteristics). Participants who are not the head of the households may be the most interested in reducing the exposure of their savings to the demands by others in the household. Relatedly, having conflicts with one's partner over monetary issues increases take-up by 5 percentage points, an increase of 13 percent. Those with more conflict might feel more of a need to put their resources out of reach of their partner.

Consistent with Dupas and Robinson (2013b), we also find that individuals who are "socially taxed" - i.e. those who lend to friends and family but do not receive such 
loans themselves - are significantly more likely to take up the accounts. Socially taxed participants are 7 percentage points more likely to open and use the account, an increase of $17 \%$ percent. Separating the two components of being socially taxed in Column (3), we find the expected sign on both dimensions. Individuals who lent money to relatives or friends are 5 percentage points more likely to take up the account, and there is a statistically insignificant negative correlation of 2 percentage points for those who owe money to family or friends. The correlations of take-up with both the household dynamics and with being socially taxed suggest that other-control problems may be an important driver of the demand for formal savings accounts.

The evidence on the role of self-control problems for take-up is mixed. Our two measures indicating possible self-control problems - regret about not having saved more, and hyperbolic time preferences ${ }^{21}$ - show somewhat different results. On the one hand, hyperbolic individuals are 5.5 percentage points more likely to take up the savings account. ${ }^{22}$ On the other hand, participants who indicate regretting not having saved more (and for which analysis described above finds that they reduce lending to others in response to receiving access to the account), are not significantly more likely to open the account.

A third potential motivation for opening an account, in addition to self- and othercontrol problems, could be safety concerns. However, we do not find that fear of having one's savings stolen affects take-up in a significant way. With respect to the sociodemographic variables in Panel A, younger people and men are less likely to take up the account. The former is consistent with statements from the focus groups that young people are more likely to rely on their parents for a financial safety cushion and may therefore not need precautionary savings as much. The latter is consistent with the social norm in Chile that women tend to be in charge of household savings. Finally, it is interesting to note the role of income. Lower income is associated with lower take-up. This is consistent with Karlan and Zinman (2012) and Dupas and Robinson (2013a) who find a positive association of wealth and income, respectively, with take-up of a savings account. Access to an account may therefore not reach the poorest of the poor to the desired extent. This reinforces the pattern found in many settings that getting buy-in by the lowest income

\footnotetext{
${ }^{21}$ Hyperbolic preferences are determined by giving survey participants hypothetical choices between $x$ pesos in time $t$ and $y$ pesos $(x<y)$ in time $t+1$ month, similar to e.g., Ashraf et al. (2006b) and Meier and Sprenger (2010).

${ }^{22}$ This is consistent with Ashraf et al. (2006b), who find that individuals with hyperbolic time preferences demonstrate a preference for commitment devices. Testing for subsequent usage, we find that being hyperbolic does not reduce the probability of using the account conditional on opening one, and contrary to the findings of Ashraf et al. (2006b), does not lead to a greater variance in the account balance.
} 
population for socially beneficial programs can be challenging.

\subsection{Robustness Checks}

In the following section, we first analyze two potential threats to the validity of the analysis: demand effects and attrition. We then analyze whether the effects are driven by the sub-treatment, i.e. the additional alleviation of self-control constraints through the peer group commitment device.

\section{Demand Effects}

Demand effects refer to changes in behavior by experimental subjects due to cues about what constitutes appropriate behavior (e.g., Crowne and Marlowe, 1964; Zizzo, 2010). In the context of this study, one concern is that participants who received access to a savings account through FE might report more positive answers in the follow-up survey out of gratitude or a sense of indebtedness towards the organization. This is not very likely to be the case here, since participants did not know that the survey was related to the savings account. ${ }^{23}$ Even so, we included two questions in the survey specifically designed to test for possible demand effects. The goal was to include questions that would be particularly susceptible to demand effects.

[Table 8]

The first question (at the very beginning of the survey) asked participants how complicated they found the process of scheduling the interview. The second question was asked at the very end of the survey, in case participants would find out during the survey that it was related to the savings account. This question asked participants how satisfied they were with FE. Table 8 shows that neither of these questions respond to the treatment. Participants receiving the treatment rated the difficulty of the survey process as 0.04 points higher compared to 2.45 of the control group (on a scale from 1 to 4 ) and satisfaction with FE as 0.01 point lower compared to 6.38 of the control group (on a scale from 1 to 7 ), with neither effect being close to statistical significance. This gives us reassurance that the self-reported findings in this paper are not driven by demand effects.

\footnotetext{
${ }^{23}$ Participants knew that the survey was from FE, but FE has many different activities and products and no specific mention of the savings account was made when presenting the survey.
} 


\section{Attrition}

In order to ensure the inclusion of individuals who were no longer members of $\mathrm{FE}$, the follow-up survey was administered at the participants' home or business location. Despite special efforts aimed at limiting attrition, ${ }^{24} 14.2 \%$ of participants could not be found for the follow-up survey. Column 2 in Table A6 in the Appendix shows that when comparing attrition rates across the treatment and control groups, we find that attrition is 2.8 percentage points higher in the treatment group. Using data from the baseline survey, we can see that attrition is not fully balanced on characteristics. Participants who are younger, live in smaller households, have more previous savings, or less short-term lending in the baseline period are less likely to be found for the follow-up survey. Even though, as shown in Columns (3) and (4) of Table 1, overall characteristics are still balanced between the treatment and control groups among the non-attritors, the differential attrition still raises some concerns about a potential bias being introduced.

Given the fact that we use individual fixed effects, the analysis is controlling for all time-invariant characteristics. We can therefore rule out any bias resulting from timeinvariant differences in the composition of treatment and control group. What we cannot rule out, however, is that the somewhat different attrition rates between treatment and control groups lead to differential trends over time among the non-attritors.

We address this concern in two ways. First, we use the bounding approach of Lee (2005) to construct upper and lower bounds for the treatment effect. Lee bounds are based on trimming the distribution of the outcome variable once from each end of the distribution by a "trimming proportion." That proportion corresponds to the difference in attrition rates between the treatment and control group as a proportion of the retention rate of the treatment group, which is in our case 3.2\%. Table A7 in the Appendix shows that the coefficients do not change their sign within these conservative Lee bounds. The range of the treatment effects on borrowing is between 3,140 and 13,839 pesos for the total amount of outstanding short-term debt, and between 0.08 and 0.14 for the number of categories. With respect to self-reported well-being, the effect ranges from 0.08 to 0.17 standard deviations for anxiety about the financial future and from 0.06 to 0.12 standard deviations for recent economic difficulty.

\footnotetext{
${ }^{24}$ During the baseline survey, we asked participants not only for their own contact information, but also for the contact details of a close relative or friend through whom they could be reached. In addition, we chose to work with the survey agency Microdatos, which has special expertise in following participants for panel studies.
} 
Second, we recalculate the main results by reweighting our sample to compensate for the differential composition between treatment and control groups using inverse probability weights (Wooldridge, 2002, 2007). This approach first predicts the probability that based on observables, a participant will be in the follow-up survey, by using a probit regression. ${ }^{25}$ Thereafter, each individual is weighted with the inverse of this probability. Those who are less likely to be part of the follow-up survey hence receive a higher weight, leading participants with characteristics that are underrepresented in the follow-up survey to be counted more heavily.

All results remain qualitatively unchanged when applying inverse probability weights (see Table A8 in the Appendix). Being in the treatment group reduces the total amount of outstanding short-term debt by 12,931 pesos without, and by 13,930 pesos with the attrition weights. The number of categories that participants are indebted to is reduced by 0.13 both with and without attrition weights. On the question of the participant's anxiety about their financial future, treatment improved the average response by 0.11 standard deviations without attrition weights, and by 0.12 standard deviations with the weights. For recent economic difficulty, the improvement is 0.09 standard deviations without and 0.10 with attrition weights. Finally, being in the treatment group reduces the consumption cutback index for individuals who had a shock by 0.38 units without, and by 0.40 with attrition weights. Overall, reweighting the analysis to account for the slightly different attrition proportion between treatment and control group does not substantially affect the magnitudes of any of our main results.

\section{Differential Effects by Type of Account}

As discussed in Section 2.3, for half of the sample, the access to the formal savings account was accompanied by a peer group savings commitment device. ${ }^{26}$ This commitment device was designed to additionally remove barriers to savings by reducing self-control problems and has been found by Kast et al. (2013) to significantly increase savings in the accounts. It is therefore of interest to understand whether the results we find in

\footnotetext{
${ }^{25}$ The following variables are used to construct the weights: all main outcome variables at baseline, all variables for which there is a significant difference between attritors and non-attritors in Table A6, and a number of additional characteristics which assure that conditional on all weight variables, being in the treatment group is no longer statistically significantly associated with attrition $(\mathrm{p}=0.152)$.

${ }^{26}$ In the groups that had been selected for the peer group savings commitment device, participants had the option of making a pledge as to how much they were going to deposit into the account every week. In the regular group meetings, participants followed up on each other's commitments and checked who had a deposit slip to prove that they had made their weekly deposit.
} 
this paper are mainly driven by the subgroup who received the peer group support, or whether they are also present for those who simply received access to the formal savings account. Splitting the sample in half to compare the subgroups with and without peer group support leads to a loss in statistical power since the number of observations in each sub-treatment is smaller. This will tend to reduce the level of significance for individual coefficients, so some of what follows is more of a suggestive nature.

[Table 9]

Table 9 shows the results for those with just the basic account, and the difference for those with the additional peer group support. The first pattern to notice is that overall, the peer group support does not seem to be driving the results. For three of the five coefficients, the effect is not stronger for those with the additional peer group support. The statistical power is generally reduced when just looking at the subgroups, but the impact on two of the key variables, i.e. the reduction in categories of debt and in consumption cutbacks, remain statistically significant when looking just at those who did not receive the additional peer group support. The effect on the self-assessed recent economic difficulty is no longer statistically significant but actually somewhat larger among those with just the basic account without the peer group treatment. The reduction in the amount of short-term borrowing is larger for those in the peer group treatment, but this difference is also not statistically significant.

The one outcome for which there is a significantly stronger effect for those with the added deposit commitment device is the reduction in anxiety about the financial future. Intuitively, it makes sense that those who have accumulated a higher buffer stock of savings in the account would have the most improvement in this forward-looking measure.

\section{Discussion and Conclusion}

This paper investigates the impact of access to a free, liquid savings account for a lowincome population in Chile. When given access to the saving accounts, participants substitute short-term informal credit with formal savings. They have less outstanding debt and owe money to fewer categories of creditors. This behavior reveals that even though in principle, participants could save at home or store money in their micro-business 
or in easily liquefiable assets, these forms of savings are not equivalent to savings in the formal savings account, and are in fact quite costly.

If savings and credit are substitute mechanisms for consumption smoothing, the question arises whether reducing barriers to saving through a free savings account mainly leads to a replacement of credit by savings, or whether overall smoothing is increased in addition. Looking at consumption smoothing as well as two self-reported welfare measures, we find that the overall level of self-insurance increases substantially. For all three measures, the effect corresponds in magnitude to about half or more of the change in that measure associated with a job loss or severe income shock. Finally, the savings behavior interacts with the social environment: take-up is particularly high for those who are more socially taxed by demands from their network, and in turn those who originally regretted not having saved more reduce their lending to others.

These results have a number of implications for research and policy. First, as discussed in the introduction, they add to the growing evidence on the benefits of facilitating savings on a variety of outcomes. These positive findings suggest that increasing access to savings vehicles may be an effective way of improving the welfare of the poor. However, private banks often do not find it in their interest to host savings accounts for low amounts and charge such accounts with administrative hurdles, minimum balance requirements, and maintenance fees, which can result in large negative interest rates. Given this lack of private incentives, governments may have a role to play in facilitating access. Reducing access costs would make formal savings more accessible to the poor. At the same time, our survey results also suggest that reducing mental barriers and fear of entering a bank, or generating trust by providing endorsement by a credible institution, may play an important role in encouraging take-up, consistent with the findings of Cole et al. (2013b) for the case of micro-insurance. ${ }^{27}$ In designing these policies, more research is required to study which contexts best allow for the different benefits of savings to be realized, for example, with respect to the optimal level of liquidity, or for settings within or outside of microfinance organizations. ${ }^{28}$

\footnotetext{
${ }^{27}$ Free basic current accounts, for example, such as very recently introduced by the Chilean government, may play an important role in providing access to savings. Similarly, policies that facilitate deposits into savings accounts, such as dispensing welfare payments into government-provided savings accounts rather than paying them out in cash, as currently considered by several countries, also have potentially large benefits. On the other hand, based on the companion paper of this study (Kast et al., 2013), which shows little response to a large increase in the interest rate, subsidies to the returns may be a less effective tool for encouraging savings.

${ }^{28}$ Microfinance clients might be different from others in many regards, such as financial literacy, en-
} 
Second, while many studies have found that withdrawal commitment devices, which limit the liquidity of the accounts, can help people build their savings, this illiquidity may come at a cost, as it reduces the usefulness of the savings for precautionary purposes by impeding discretionary use in times of need. ${ }^{29}$ This suggests that depending on the goal a particular savings vehicle is meant to serve, and depending on the savings constraints, different levels of liquidity may be optimal. It is noteworthy that a liquid savings account with no withdrawal restrictions is not necessarily at odds with facilitating longer-term investments, e.g. for health and education, as found by (Prina, 2013) in Nepal. It may be important in this regard to distinguish liquidity (in terms of a lack of withdrawal restrictions) from ease and speed of access (e.g. through a debit card or mobile phone banking). Too much accessibility may reduce the benefits of formal savings accounts away from the home. ${ }^{30}$ An effective setup for precautionary savings might therefore be characterized by a liquid account without withdrawal limits, but with some degree of friction in the withdrawal process. More research is required to analyze this tradeoff of liquidity for commitment devices available for this need.

Third, the finding that those who initially regretted not having saved more are less likely to provide credit to others in their social network after receiving access to the account raises some questions about the overall social impact. However, these findings have to be interpreted with caution, since we did not start the analysis with this subgroup in mind, and it will be important to test their replicability. If these results hold, the overall social impact is a priori ambiguous. On the one hand, access to savings vehicles increases the peace of mind of those who can use them. In addition, if it lowers the pressure to share money with others, this may reduce the disincentive effect of such a 'social tax' (e.g., Alger and Weibull, 2010; Jakiela and Ozier, 2012). On the other hand, the reduced lending may diminish the welfare of others in participants' social network. Further research is required to investigate these general equilibrium and distributional effects.

Finally, our results show that precautionary savings can, to some degree, provide an alternative mechanism to formal insurance. This may be particularly important in

trepreneurial spirit, having significant debt at the same time, or being more experienced with financial institutions.

${ }^{29}$ In contrast, deposit commitment devices such as in e.g. Madrian and Shea (2001); Thaler and Benartzi (2004); Ashraf et al. (2006a) and Kast et al. (2013) encourage the deposit margin without necessarily restricting withdrawals.

${ }^{30}$ Too much ease of access may not only exacerbate self-control problems (e.g. in the form of impulsespending), but also other-control problems, as it can make it easier for others to pressure the saver to disclose and share the savings (Schaner, 2013). 
environments in which access to formal insurance options is limited. While insurance contracts could in principle often provide protection from economic shocks at a lower cost than self-insurance through savings, one benefit of self-insurance is that it does not suffer from the two-sided asymmetric information problem that formal insurance products can be faced with. In low-income environments, it is often not only difficult for the insurer to verify the validity of insurance claims, but also for the insurance clients to trust that the insurers will keep their future obligations. This is one of the reasons why providing insurance to low-income populations in developing countries faces many challenges, even for risks that seem to present relatively few problems of moral hazard or adverse selection, such as weather risks (e.g., Giné and Yang, 2009; Cai et al., 2012; Giné et al., 2012; Cole et al., 2013b). In addition, even for situations in which micro-insurance has been successfully provided, there is no clear evidence yet on whether micro-insurance helps participants smooth consumption. ${ }^{31}$ While for low-probability, high-loss events, self-insurance through savings would be very costly and often not realistic, it may provide an effective alternative for smaller loss, higher probability events such as short-term income shocks.

\footnotetext{
${ }^{31}$ Several studies do, however, find that weather insurance can help farmers make riskier decisions (e.g., Vargas Hill and Viceisza, 2010; Cai, 2012; Karlan et al., 2012; Mobarak and Rosenzweig, 2012; Cole et al., 2013a).
} 


\section{References}

Ahmed, Naeem, Matthew Brzozowski, and Thomas Crossley, "Measurement Errors in Recall Food Consumption Data," IFS Working Papers, 2006.

Alderman, Harold, "Saving and Economic Shocks in Rural Pakistan," Journal of Development Economics, 1996, 51 (2), 343-365.

Alger, Ingela and Jörgen W. Weibull, "Kinship, Incentives, and Evolution," American Economic Review, 2010, 100 (4), 1725-1758.

Ananth, Bindu, Dean Karlan, and Sendhil Mullainathan, "Microentrepreneurs and their Money: Three Anomalies," Innovations for Poverty Action: Financial Access Initiative, 2007.

Anderson, Siwan and Jean-Marie Baland, "The Economics of ROSCAs and Intrahousehold Resource Allocation," Quarterly Journal of Economics, 2002, 117 (3), 963-995.

Angelucci, Manuela, Dean Karlan, and Jonathan Zinman, "Win Some Lose Some? Evidence from a Randomized Microcredit Program Placement Experiment by Compartamos Banco," Technical Report, National Bureau of Economic Research 2013.

Ashraf, Nava, Dean Karlan, and Wesley Yin, "Deposit Collectors," Advances in Economic Analysis \& Policy, 2006, 6 (2), Article 5.

_ , _ , and _ , "Tying Odysseus to the Mast: Evidence from a Commitment Savings Product in the Philippines," Quarterly Journal of Economics, 2006, 121 (1), 635-672.

_ , _ , and _ , "Female Empowerment: Impact of a Commitment Savings Product in the Philippines," World Development, 2010, 38 (3), 333-344.

Atkinson, Jesse, Alain de Janvry, Craig McIntosh, and Elisabeth Sadoulet, "Prompting Microfinance Borrowers to Save: A Behavioral Experiment from Guatemala," Economic Development and Cultural Change, 2013, 62 (1), 21-64.

Baland, Jean-Marie, Catherine Guirkinger, and Charlotte Mali, "Pretending to be Poor: Borrowing to Escape Forced Solidarity in Cameroon," Economic Development and Cultural Change, 2011, 60 (1), 1-16.

Banerjee, Abhijit and Esther Duflo, "The Economic Lives of the Poor," Journal of Economic Perspectives, 2007, 21 (1), 141-167.

Barr, Michael S, No Slack: The Financial Lives of Low-income Americans, Brookings Institution Press, 2012.

Besley, Timothy, "Savings, Credit and Insurance," Handbook of Development Economics, 1995, 3, 2123-2207.

Browning, Martin and Annamaria Lusardi, "Household Saving: Micro Theories and Micro Facts," Journal of Economic Literature, 1996, 34 (4), 1797-1855.

Brune, Lasse, Xavier Giné, Jessica Goldberg, and Dean Yang, "Commitments to Save: a Field Experiment in Rural Malawi," Policy Research Working Paper 5748, 2011, Development Research Group, The World Bank.

Burgess, Robin and Rohini Pande, "Do Rural Banks Matter? Evidence from the Indian Social Banking Experiment," American Economic Review, 2005, 95 (3), 780-795.

Cai, Hongbin, Yuyu Chen, Hanming Fang, and Li-An Zhou, "The Effect of Microinsurance on Economic Activities: Evidence from a Randomized Field Experiment," 2012.

Cai, Jing, "The Impact of Insurance Provision on Households' Production and Financial Decisions," Working Paper, 2012.

Cattaneo, Matias D., Sebastian Galiani, Paul J. Gertler, Sebastian Martinez, and Rocio Titiunik, "Housing, Health, and Happiness," American Economic Journal: Economic 
Policy, 2009, 1 (1), 75-105.

Chandrasekhar, Arun, Cynthia Kinnan, and Horacio Larreguy, "Informal Insurance, Social Networks, and Savings Access: Evidence from a Framed Field Experiment," MIT Working Paper, 2012.

Clingingsmith, David, Asim I. Khwaja, and Michael Kremer, "Estimating the Impact of the Hajj: Religion and Tolerance in Islam's Global Gathering," Quarterly Journal of Economics, 2009, 124 (3), 1133-1170.

Cole, Shawn, Thomas Sampson, and Bilal Zia, "Prices or Knowledge? What Drives Demand for Financial Services in Emerging Markets?," Journal of Finance, 2011, 66 (6), 1933-1967.

_ , Xavier Giné, and James Vickery, "How Does Risk Management Influence Production Decisions? Evidence from a Field Experiment," Harvard Busines School, Working paper 13080, 2013.

_ , _ , Jeremy Tobacman, Petia Topalova, Robert Townsend, and James Vickery, "Barriers to Household Risk Management: Evidence from India," American Economic Journal: Applied Economics, 2013, 5 (1), 104-135.

Collins, Daryl, Jonathan Morduch, Stuart Rutherford, and Orlanda Ruthven, Portfolios of the Poor: How the World's Poor Live on \$2 a Day, Princeton University Press, 2009.

Comola, Margherita and Silvia Prina, "Intervention-Driven Changes in Social Networks and Their Effects on Household Outcomes," Working Paper, 2013.

Crowne, Douglas P. and David Marlowe, The Approval Motive, New York: Wiley, 1964.

Deaton, Angus, "Saving and liquidity constraints," Econometrica, September 1991, 59 (5), 1221-1248.

_, The Analysis of Household Surveys: A Microeconometric Approach to Development Policy, Baltimore: Johns Hopkins University Press for the World Bank, 1997.

Devoto, Florencia, Esther Duflo, Pascaline Dupas, William Pariente, and Vincent Pons, "Happiness on Tap: Piped Water Adoption in Urban Morocco," American Economic Journal: Economic Policy, 2012, 4 (4), 68-99.

Dezső, Linda and George Loewenstein, "Lenders Blind Trust and Borrowers Blind Spots: A Descriptive Investigation of Personal Loans," Journal of Economic Psychology, 2012.

Dupas, Pascaline and Jonathan Robinson, "Savings Constraints and Microenterprise Development: Evidence from a Field Experiment in Kenya," American Economic Journal: Applied Economics, 2013, 5 (1), 163-192.

_ and _ , "Why Don't the Poor Save More? Evidence from Health Savings Experiments," The American Economic Review, 2013, 103 (4), 1138-71.

_, Green Sarah, Keats Anthony, and Jonathan Robinson, "Challenges in Banking the Rural Poor: Evidence from Kenya's Western Province," National Bureau of Economic Research, 2012, Africa Project Conference.

Fafchamps, Marcel, "Contraintes de Crédit, Collatéral et Prêts aux Pauvres," Revue d'économie du développement, 2013, 27 (2), 79-100.

- and Susan Lund, "Risk-Sharing Networks in Rural Philippines," Journal of Development Economics, 2003, 71 (2), 261-287.

FDIC, Unbanked/Underbanked Survey Study Group, "FDIC National Survey of Unbanked and Underbanked Households," Federal Deposit Insurance Corporation, 2011.

Ferrara, Eliana La, "Kin Groups and Reciprocity: A Model of Credit Transactions in Ghana," 
The American Economic Review, 2003, 93 (5), 1730-1751.

Field, Erica, Rohini Pande, John Papp, and Natalia Rigol, "Does the Classic Microfinance Model Discourage Entrepreneurship Among the Poor? Experimental Evidence from India," American Economic Review, 2012.

Flory, Jeffrey A., "Micro-Savings \& Informal Insurance in Villages:How Does Financial Deepening Affect Safety Nets of the Very Poor?," Working Paper 2011-008, 2012, Becker Friedman Institute for Research in Economics.

Galesic, Mirta and Michael Bosnjak, "Effects of Questionnaire Length on Participation and Indicators of Response Quality in a Web Survey," Public Opinion Quarterly, 2009, 73 (2), 349-360.

Giné, Xavier and Dean Yang, "Insurance, Credit, and Technology Adoption: Field Experimental Evidence from Malawi," Journal of Development Economics, 2009, 89 (1), 1-11.

_, Lev Menand, Robert Townsend, and James Vickery, Microinsurance: A Case Study of the Indian Rainfall Index Insurance Market, in Ghate, C. (ed) Handbook of the Indian Economy, Oxford University Press, USA, 2012.

Haushofer, Johannes, Joost de Laat, and Matthieu Chemin, "Poverty Raises Levels of the Stress Hormone Cortisol: Evidence from Weather Shocks in Kenya," Working Paper, 2012 .

Hertzberg, Andrew, "Exponential Individuals, Hyperbolic Households," Working Paper Graduate School of Business, Columbia University, 2010.

Herzog, A. Regula and Jerald G. Bachman, "Effects of Questionnaire Length on Response Quality," Public Opinion Quarterly, 1981, 45 (4), 549-559.

Hill, Ruth Vargas and Angelino Viceisza, "An Experiment on the Impact of Weather Shocks and Insurance on Risky Investment," Discussion Paper 00974, 2010, International Food Policy Research Institute.

Jack, William and Tavneet Suri, "Risk sharing and Transaction Costs: Evidence from Kenyas Mobile Money Revolution," American Economic Review, 2014, 104 (1), 183-223.

Jacoby, Hanan G. and Emmanuel Skoufias, "Risk, Financial Markets, and Human Capital in a Developing Country," Review of Economic Studies, 1997, 64 (3), 311-335.

Jakiela, Pamela and Owen Ozier, "Does Africa Need a Rotten Kin Theorem? Experimental Evidence from Village Economies," World Bank Policy Research Working Paper, 2012.

Karlan, Dean and Jonathan Zinman, "Price and Control Elasticities of Demand for Savings," Working Paper, 2012.

_ and Sendhil Mullainathan, "Rigidity in Microfinancing: Can One Size Fit All?," 2010.

_, Isaac Osei-Akoto, Robert Darko Osei, and Christopher Udry, "Agricultural Decisions after Relaxing Credit and Risk Constraints," Working Paper 110, 2012, Economics Department, Yale University.

Kast, Felipe, Stephan Meier, and Dina Pomeranz, "Under-Savers Anonymous: Evidence on Self-Help Groups and Peer Pressure as a Savings Commitment Device," NBER Working Paper No. 18417, 2013.

Kinnan, Cynthia and Robert Townsend, "Kinship and Financial Networks, Formal Financial Access and Risk Reduction," American Economic Review Papers and Proceedings, 2012, 102 (2), 289-293.

Kling, Jeffrey, Jeffrey Liebman, Lawrence Katz, and Lisa Sanbonmatsu, "Moving to Opportunity and Tranquility: Neighborhood Effects on Adult Economic Self-Sufficiency and Health from a Randomized Housing Voucher Experiment," Faculty Research Working Papers 
Series, 2004, Harvard University, John F. Kennedy School of Government.

Kuruvilla, Anju and K.S. Jacob, "Poverty, Social Stress \& Mental Health," Indian Journal of Medical Research, 2007, 126 (4), 273.

Lee, David S., "Training, Wages, and Sample Selection: Estimating Sharp Bounds on Treatment Effects," NBER Working Paper 11721, 2005, National Bureau of Economic Research.

Ligon, Ethan, Jonathan P Thomas, and Tim Worrall, "Informal Insurance Arrangements with Limited Commitment: Theory and Evidence from Village Economies," The Review of Economic Studies, 2002, 69 (1), 209-244.

Ludwig, Jens, Greg Duncan, Lisa Gennetian, Lawrence Katz, Ronald Kessler, Jeffrey Kling, and Lisa Sanbonmatsu, "Neighborhood Effects on the Long-Term Well-Being of Low-Income Adults," Science, 2012, 337 (6101), 1505-1510.

Lusardi, Annamaria, Daniel J. Schneider, and Peter Tufano, "Financially Fragile Households: Evidence and Implications," NBER Working Paper 17072, 2011.

Madrian, Brigitte and Dennis Shea, "The Power of Suggestion: Inertia in 401(k) Participation and Savings Behavior," Quarterly Journal of Economics, 2001, 116 (4), 1149-1187.

Mazzocco, Maurizio and Shiv Saini, "Testing Efficient Risk Sharing with Heterogeneous Risk Preferences," The American Economic Review, 2012, 102 (1), 428-468.

Meier, Stephan and Charles Sprenger, "Present-Biased Preferences and Credit Card Borrowing," American Economic Journal: Applied Economics, 2010, 2 (1), 193-210.

Mel, Suresh De, David J. McKenzie, and Christopher Woodruff, "Measuring Microenterprise Profits: Must We Ask How the Sausage is Made?," Journal of Development Economics, 2009, 88 (1), 19-31.

Mobarak, Ahmed and Mark Rosenzweig, "Selling Formal Insurance to the Informally Insured," Yale University Economic Growth Center Discussion Paper, 2012, (1007).

Morduch, Jonathan, "Income Smoothing and Consumption Smoothing," Journal of Economic Perspectives, 1995, 9 (3), 103-114.

Munshi, Kaivan and Mark Rosenzweig, "Why is Social Mobility in India So Low? Social Insurance, Inequality, and Growth," NBER Working Paper 14850, 2009, National Bureau of Economic Research.

Paxson, Christina H., "Using Weather Variability to Estimate the Response of Savings to Transitory Income in Thailand," The American Economic Review, 1992, pp. 15-33.

Prina, Silvia, "Banking the Poor Via Savings Accounts: Evidence from a Field Experiment," Case Western Reserve Working Paper, 2013.

Roodman, David, Due Diligence: An Impertinent Inquiry into Microfinance, CGD Books, 2012.

Rosenzweig, Mark and Hans Binswanger, "Wealth, Weather Risk and the Composition and Profitability of Agricultural Investments," The Economic Journal, 1993, 103 (416), 56-78.

_ and Kenneth I. Wolpin, "Credit Market Constraints, Consumption Smoothing, and the Accumulation of Durable Production Assets in Low-Income Countries: Investments in Bullocks in India," Journal of Political Economy, 1993, pp. 223-244.

Schaner, Simone, "Intrahousehold Preference Heterogeneity, Commitment, and Strategic Savings: Theory and Evidence from Kenya," Working Paper, 2011.

_ , "The Cost of Convenience? Transaction Costs, Bargaining Power, and Savings Account Use in Kenya," Working Paper, 2013.

Schicks, Jessica, "The Definition and Causes of Microfinance Over-Indebtedness: A Customer Protection Point of View," Oxford Development Studies, 2013, (ahead-of-print), 1-22. 
Shah, Anuj, Sendhil Mullainathan, and Eldar Shafir, "Some Consequences of Having Too Little," Science, 2012, 338 (6107), 682-685.

Taylor, Mark P., David J. Pevalin, and Jennifer Todd, "The Psychological Costs of Unsustainable Housing Commitments," Cambridge University Press, 2006.

Thaler, Richard and Shlomo Benartzi, "Save More Tomorrow ${ }^{\mathrm{TM}}$ : Using Behavioral Economics to Increase Employee Saving," Journal of Political Economy, 2004, 112 (S1), 164-187.

Townsend, Robert, "Risk and Insurance in Village India," Econometrica, 1994, pp. 539-591.

_ , "Financial Systems in Northern Thai Villages," Quarterly Journal of Economics, 1995, 110 (4), 1011-1046.

Udry, Christopher, "Risk and Saving in Northern Nigeria," The American Economic Review, 1995, 85 (5), 1287-1300.

Washington, Ebonya, "The Impact of Banking and Fringe Banking Regulation on the Number of Unbanked Americans," Journal of Human Resources, 2006, 41 (1), 106-137.

Wooldridge, Jeffrey, "Inverse Probability Weighted M-Estimators for Sample Selection, Attrition, and Stratification," Portuguese Economic Journal, 2002, 1 (2), 117-139.

_ , "Inverse Probability Weighted Estimation for General Missing Data Problems," Journal of Econometrics, 2007, 141 (2), 1281-1301.

Zame, William, "Efficiency and the Role of Default when Security Markets are Incomplete," American Economic Review, 1993, 83 (1), 1142-1164.

Zinman, Jonathan, "Household Borrowing Bigh and Lending Low Under No-Arbitrage," Dartmouth University, 2007.

Zizzo, Daniel, "Experimenter Demand Effects in Economic Experiments," Experimental Economics, 2010, 12 (1), 75-98.

Zwane, Alix Peterson, Jonathan Zinman, Eric Van Dusen, William Pariente, Clair Null, Edward Miguel, Michael Kremer, Dean S. Karlan, Richard Hornbeck, Xavier Giné, Esther Duflo, Devoto Florencia, Bruno Crepon, and Abhijit Banarjee, "Being Surveyed Can Change Later Behavior and Related Parameter Estimates," Proceedings of the National Academy of Sciences, 2011, 108 (5), 1821-1826. 
Table 1: Baseline Summary Statistics and Balance of Randomization

\begin{tabular}{|c|c|c|c|c|}
\hline & \multicolumn{2}{|c|}{ Full Sample } & \multicolumn{2}{|c|}{ Excluding Attritors } \\
\hline & (1) & $(2)$ & (3) & $(4)$ \\
\hline & $\begin{array}{c}\text { Control } \\
\text { means }\end{array}$ & $\begin{array}{l}\text { Difference: } \\
\text { treatment - control }\end{array}$ & $\begin{array}{l}\text { Control } \\
\text { means }\end{array}$ & $\begin{array}{c}\text { Difference: } \\
\text { treatment - control }\end{array}$ \\
\hline \multirow{2}{*}{ Age } & 43.29 & 0.10 & 43.44 & 0.12 \\
\hline & (11.61) & $(0.44)$ & $(11.55)$ & $(0.47)$ \\
\hline \multirow[t]{2}{*}{ Years of education } & 9.81 & -0.16 & 9.76 & -0.13 \\
\hline & $(3.12)$ & $(0.16)$ & $(3.08)$ & $(0.16)$ \\
\hline \multirow[t]{2}{*}{ Household size } & 4.27 & 0.06 & 4.30 & 0.05 \\
\hline & $(1.73)$ & $(0.07)$ & $(1.69)$ & $(0.07)$ \\
\hline & 79,955 & 564 & 79,419 & 965 \\
\hline \multirow{2}{*}{ household income } & $(64,495)$ & $(2,492)$ & $(65,695)$ & $(2,622)$ \\
\hline & {$[66,000]$} & {$[1,500]$} & {$[65,429]$} & {$[1,571]$} \\
\hline \multirow[t]{2}{*}{ Has prior savings account } & 0.32 & 0.01 & 0.32 & 0.01 \\
\hline & $(0.47)$ & $(0.02)$ & $(0.47)$ & $(0.02)$ \\
\hline \multirow[t]{3}{*}{ Prior formal savings amount } & 63,260 & 5,720 & 60,408 & 2,984 \\
\hline & $(241,301)$ & $(8,541)$ & $(225,865)$ & $(8,335)$ \\
\hline & {$[0]$} & {$[0]$} & {$[0]$} & {$[0]$} \\
\hline \multirow{3}{*}{ Short-term borrowing amount } & 165,957 & $-61,059$ & 171,272 & $-65,063$ \\
\hline & $(1,642,180)$ & $(44,801)$ & $(1,741,846)$ & $(50,762)$ \\
\hline & {$[0]$} & {$[0]$} & {$[0]$} & {$[0]$} \\
\hline \multirow{2}{*}{$\begin{array}{l}\text { Short-term borrowing amount } \\
\text { (winsorized at } 95 \% \text { ) }\end{array}$} & 65,616 & $-3,613$ & 66,692 & $-4,699$ \\
\hline & $(130,687)$ & $(5,085)$ & $(131,801)$ & $(5,162)$ \\
\hline \multirow{2}{*}{$\begin{array}{l}\text { Short-term borrowing } \\
\text { categories }\end{array}$} & 0.91 & 0.03 & 0.91 & 0.05 \\
\hline & $(1.13)$ & $(0.05)$ & $(1.12)$ & $(0.05)$ \\
\hline \multirow[t]{3}{*}{ Short-term lending amount } & 110,118 & 28,101 & 114,074 & 30,936 \\
\hline & $(621,082)$ & $(27,169)$ & $(660,584)$ & $(31,464)$ \\
\hline & {$[13,000]$} & {$[2,000]$} & {$[15,000]$} & {$[0]$} \\
\hline \multirow{2}{*}{$\begin{array}{l}\text { Short-term lending amount } \\
\text { (winsorized at } 95 \% \text { ) }\end{array}$} & 68,763 & 6,256 & 68,052 & 6,963 \\
\hline & $(113,236)$ & $(4,451)$ & $(111,995)$ & $(4,732)$ \\
\hline \multirow[t]{2}{*}{ Short-term lending categories } & 1.07 & 0.06 & 1.08 & 0.05 \\
\hline & $(1.20)$ & $(0.05)$ & $(1.19)$ & $(0.05)$ \\
\hline \multirow[t]{2}{*}{ Need to cut back consumption } & 0.70 & 0.01 & 0.70 & 0.01 \\
\hline & $(0.46)$ & $(0.02)$ & $(0.46)$ & $(0.02)$ \\
\hline \multirow[t]{2}{*}{ Anxious about financial future } & 2.90 & 0.04 & 2.91 & 0.04 \\
\hline & $(0.97)$ & $(0.04)$ & $(0.97)$ & $(0.05)$ \\
\hline \multirow[t]{2}{*}{ Recent economic difficulty } & 5.03 & 0.14 & 5.00 & 0.18 \\
\hline & $(2.79)$ & $(0.12)$ & $(2.78)$ & $(0.13)$ \\
\hline $\begin{array}{l}\text { Number of individuals in } \\
\text { control and treatment group }\end{array}$ & 1,488 & 2,687 & 1,304 & 2,279 \\
\hline
\end{tabular}

Notes: Columns (1) and (3) show the control group mean for the full sample and the sample excluding the attritors respectively, with the standard deviation in parenthesis. Columns (2) and (4) show the coefficients of regressions of the pre-treatment variable in question on a treatment dummy, with robust standard errors, clustered at the group level, in parenthesis. Medians are displayed in brackets, and all financial figures are in Chilean pesos. 500 Chilean pesos = about 1 USD. The variables "anxious about financial future" and "recent economic difficulty" range from 1 to 4 and 1 to 10 respectively. Level of significance: $* * * \mathrm{p}<0.01,{ }^{* *} \mathrm{p}<0.05,{ }^{*} \mathrm{p}<0.1$. 
Table 2: Descriptive Statistics On Take-Up and Account Usage

\begin{tabular}{lccc}
\hline \hline Panel A: Take-Up Statistics & & & \\
\hline & $\begin{array}{c}\text { Number of } \\
\text { individuals }\end{array}$ & $\begin{array}{c}\text { Total } \\
\text { sample }\end{array}$ & $\begin{array}{c}\text { Percent of } \\
\text { sample }\end{array}$ \\
\hline Opened account & 1,218 & 2,279 & $53 \%$ \\
Active user & 886 & 2,279 & $39 \%$ \\
\hline \hline Panel B: Account Usage Conditional on Being an Active User & & & \\
\hline & Mean & Median & Std. Dev. \\
\hline Number of deposits & 4.4 & 2 & 5.4 \\
Amount deposited & 66,898 & 9,000 & 215,523 \\
Number of withdrawals & 1.0 & 0 & 1.8 \\
Amount withdrawn & 46,664 & 0 & 148,549 \\
Average end of month balance & 18,456 & 5,000 & 77,672 \\
\hline Number of observations & 886 & 886 & 886 \\
\hline \hline
\end{tabular}

Notes: This sample is restricted to participants who are included in the follow up survey. Active user is defined as a participant who used the account beyond the minimum opening deposit. All financial figures are in Chilean pesos. 500 Chilean pesos = about 1 USD. 
Table 3: Effects on Short-Term Borrowing

\begin{tabular}{|c|c|c|c|c|}
\hline & \multirow[b]{2}{*}{$\begin{array}{c}(1) \\
\text { Total } \\
\text { short-term } \\
\text { borrowing }\end{array}$} & \multicolumn{3}{|c|}{ Components of Short-Term Borrowing } \\
\hline & & $\begin{array}{c}(2) \\
\text { Owed to } \\
\text { family and } \\
\text { friends }\end{array}$ & $\begin{array}{l}\text { (3) } \\
\text { Owed to } \\
\text { service } \\
\text { providers }\end{array}$ & $\begin{array}{c}(4) \\
\text { Owed to } \\
\text { business } \\
\text { contacts and } \\
\text { institutions }\end{array}$ \\
\hline \multicolumn{5}{|c|}{ Panel A: Amounts (Winsorized at 95th Percentile) } \\
\hline Account $\mathrm{x}$ post & $\begin{array}{c}-12,931^{* *} \\
(5,867)\end{array}$ & $\begin{array}{c}-6,480^{* * *} \\
(2,465)\end{array}$ & $\begin{array}{c}428 \\
(1,363)\end{array}$ & $\begin{array}{l}-1,689 \\
(1,694)\end{array}$ \\
\hline Post & $\begin{array}{c}226 \\
(5,006)\end{array}$ & $\begin{array}{c}2,523 \\
(2,279)\end{array}$ & $\begin{array}{l}-1,010 \\
(1,141)\end{array}$ & $\begin{array}{l}-2,655^{*} \\
(1,401)\end{array}$ \\
\hline Constant & $\begin{array}{c}61,112^{* * *} \\
(1,333)\end{array}$ & $\begin{array}{c}13,622^{* * *} \\
(510)\end{array}$ & $\begin{array}{c}12,056^{* * *} \\
(316)\end{array}$ & $\begin{array}{c}13,773^{* * *} \\
(396)\end{array}$ \\
\hline Control group mean & 64,357 & 17,053 & 10,985 & 11,380 \\
\hline \multicolumn{5}{|c|}{ Panel B: Categories of Short-Term Borrowing } \\
\hline Account $\mathrm{x}$ post & $\begin{array}{c}-0.127^{* *} \\
(0.052)\end{array}$ & $\begin{array}{c}-0.072^{* *} \\
(0.029)\end{array}$ & $\begin{array}{c}-0.057^{* *} \\
(0.027)\end{array}$ & $\begin{array}{c}0.001 \\
(0.021)\end{array}$ \\
\hline Post & $\begin{array}{c}-0.341^{* * *} \\
(0.043)\end{array}$ & $\begin{array}{c}-0.106^{* * *} \\
(0.025)\end{array}$ & $\begin{array}{c}-0.102^{* * *} \\
(0.023)\end{array}$ & $\begin{array}{c}-0.133^{* * *} \\
(0.018)\end{array}$ \\
\hline Constant & $\begin{array}{c}0.936^{* * *} \\
(0.012)\end{array}$ & $\begin{array}{c}0.304^{* * *} \\
(0.007)\end{array}$ & $\begin{array}{c}0.372^{* * * *} \\
(0.006)\end{array}$ & $\begin{array}{c}0.261^{* * *} \\
(0.005)\end{array}$ \\
\hline Control group mean & 0.571 & 0.199 & 0.235 & 0.137 \\
\hline Individual fixed effects & Yes & Yes & Yes & Yes \\
\hline Individuals & 3,572 & 3,572 & 3,572 & 3,572 \\
\hline Observations & 7,144 & 7,144 & 7,144 & 7,144 \\
\hline
\end{tabular}

Notes: For a description of the categories included in each component of short-term borrowing, see Section 2.3. Robust standard errors, clustered at the group level, reported in parenthesis. Level of significance: All financial figures are in Chilean pesos. 500 Chilean pesos $=$ about 1 USD. ${ }^{* * *} \mathrm{p}<0.01,{ }^{* *} \mathrm{p}<0.05,{ }^{*} \mathrm{p}<0.1$. 
Table 4: Effects on Lending

\begin{tabular}{|c|c|c|c|c|c|c|}
\hline & \multicolumn{3}{|c|}{ Full Sample } & \multicolumn{3}{|c|}{ Always or Frequently Regret } \\
\hline & $(1)$ & $(2)$ & $(3)$ & (4) & $(5)$ & (6) \\
\hline & $\begin{array}{l}\text { Total } \\
\text { lending }\end{array}$ & $\begin{array}{l}\text { Lent to } \\
\text { family and } \\
\text { friends }\end{array}$ & $\begin{array}{l}\text { Lent to } \\
\text { business } \\
\text { contacts }\end{array}$ & $\begin{array}{c}\text { Total } \\
\text { lending }\end{array}$ & $\begin{array}{l}\text { Lent to } \\
\text { family and } \\
\text { friends }\end{array}$ & $\begin{array}{l}\text { Lent to } \\
\text { business } \\
\text { contacts }\end{array}$ \\
\hline \multicolumn{7}{|c|}{ Panel A: Amounts (Winsorized at 95th Percentile) } \\
\hline Account $\mathrm{x}$ post & $\begin{array}{l}-3,154 \\
(5,671)\end{array}$ & $\begin{array}{l}-5,620 \\
(3,491)\end{array}$ & $\begin{array}{c}2,707 \\
(2,524)\end{array}$ & $\begin{array}{c}-11,852^{*} \\
(6,495)\end{array}$ & $\begin{array}{c}-11,783^{* * *} \\
(4,093)\end{array}$ & $\begin{array}{c}1,747 \\
(3,006)\end{array}$ \\
\hline Post & $\begin{array}{c}8,757^{* *} \\
(4,368)\end{array}$ & $\begin{array}{l}-1,241 \\
(2,778)\end{array}$ & $\begin{array}{l}3,168^{*} \\
(1,844)\end{array}$ & $\begin{array}{c}13,309 * * * \\
(5,062)\end{array}$ & $\begin{array}{c}2,390 \\
(3,235)\end{array}$ & $\begin{array}{c}2,561 \\
(2,341)\end{array}$ \\
\hline Constant & $\begin{array}{c}74,896^{* * *} \\
(1,401)\end{array}$ & $\begin{array}{c}35,739^{* * *} \\
(842)\end{array}$ & $\begin{array}{c}30,910^{* * * *} \\
(642)\end{array}$ & $\begin{array}{c}76,386^{* * *} \\
(1,595)\end{array}$ & $\begin{array}{c}37,841^{* * *} \\
(992)\end{array}$ & $\begin{array}{c}31,086^{* * *} \\
(736)\end{array}$ \\
\hline Control group mean & 79,543 & 31,599 & 34,763 & 83,099 & 34,129 & 35,657 \\
\hline \multicolumn{7}{|c|}{ Panel B: Categories of Borrowers } \\
\hline Account $\mathrm{x}$ post & $\begin{array}{l}-0.078 \\
(0.052)\end{array}$ & $\begin{array}{l}-0.047 \\
(0.037)\end{array}$ & $\begin{array}{l}-0.031 \\
(0.027)\end{array}$ & $\begin{array}{c}-0.159^{* * *} \\
(0.058)\end{array}$ & $\begin{array}{c}-0.102^{* *} \\
(0.041)\end{array}$ & $\begin{array}{c}-0.056^{*} \\
(0.032)\end{array}$ \\
\hline Post & $\begin{array}{c}-0.324^{* * *} \\
(0.042)\end{array}$ & $\begin{array}{c}-0.230^{* * *} \\
(0.030)\end{array}$ & $\begin{array}{c}-0.093^{* * *} \\
(0.021)\end{array}$ & $\begin{array}{c}-0.290^{* * *} \\
(0.045)\end{array}$ & $\begin{array}{c}-0.214^{* * *} \\
(0.031)\end{array}$ & $\begin{array}{c}-0.076^{* * *} \\
(0.024)\end{array}$ \\
\hline Constant & $\begin{array}{c}1.110^{* * *} \\
(0.012)\end{array}$ & $\begin{array}{c}0.564^{* * *} \\
(0.009)\end{array}$ & $\begin{array}{c}0.546^{* * *} \\
(0.007)\end{array}$ & $\begin{array}{c}1.145^{* * *} \\
(0.014)\end{array}$ & $\begin{array}{c}0.593^{* * *} \\
(0.010)\end{array}$ & $\begin{array}{c}0.552^{* * *} \\
(0.008)\end{array}$ \\
\hline Control group mean & 0.759 & 0.321 & 0.438 & 0.804 & 0.344 & 0.460 \\
\hline Individual fixed effects & Yes & Yes & Yes & Yes & Yes & Yes \\
\hline Individuals & 3,566 & 3,566 & 3,566 & 2,438 & 2,438 & 2,438 \\
\hline Observations & 7,132 & 7,132 & 7,132 & 4,876 & 4,876 & 4,876 \\
\hline
\end{tabular}

Notes: Participants were asked if they regretted not having saved more in the preceding three months. Columns (4)-(6) contain the sample of participants who indicated that they 'always' or 'frequently' regretted not having saved more. Robust standard errors, clustered at the group level, reported in parenthesis. All financial figures are in Chilean pesos. 500 Chilean pesos $=$ about 1 USD. Level of significance: $* * * \mathrm{p}<0.01$, ** $\mathrm{p}<0.05, * \mathrm{p}<0.10$. 
Table 5: Consumption Variation in the Face of Economic Shocks

\begin{tabular}{|c|c|c|c|c|c|c|c|c|c|}
\hline & \multicolumn{8}{|c|}{ Individual Treatment Effects } & \multirow{3}{*}{$\begin{array}{c}\text { AES } \\
(9) \\
\text { Consumption } \\
\text { variation } \\
\text { (Cols 1-8) }\end{array}$} \\
\hline & (1) & $(2)$ & $(3)$ & $(4)$ & $(5)$ & $(6)$ & $(7)$ & $(8)$ & \\
\hline & Meals & Meat & Medicines & $\begin{array}{l}\text { School } \\
\text { supplies }\end{array}$ & Clothing & $\begin{array}{l}\text { School } \\
\text { snacks }\end{array}$ & $\begin{array}{c}\text { Public } \\
\text { transport }\end{array}$ & $\begin{array}{c}\text { Eating } \\
\text { out }\end{array}$ & \\
\hline Account $\mathrm{x}$ post & $\begin{array}{l}-0.014 \\
(0.026)\end{array}$ & $\begin{array}{c}-0.083^{* *} \\
(0.039)\end{array}$ & $\begin{array}{l}-0.019 \\
(0.035)\end{array}$ & $\begin{array}{l}-0.036 \\
(0.026)\end{array}$ & $\begin{array}{l}-0.057 \\
(0.043)\end{array}$ & $\begin{array}{c}-0.040^{*} \\
(0.021)\end{array}$ & $\begin{array}{c}-0.101^{* *} \\
(0.040)\end{array}$ & $\begin{array}{l}-0.029 \\
(0.043)\end{array}$ & $\begin{array}{l}\text { Coefficient: } \\
-0.112^{* *}\end{array}$ \\
\hline Post & $\begin{array}{c}0.035 \\
(0.022)\end{array}$ & $\begin{array}{c}0.117^{* * *} \\
(0.031)\end{array}$ & $\begin{array}{l}-0.019 \\
(0.029)\end{array}$ & $\begin{array}{c}-0.052^{* * *} \\
(0.019)\end{array}$ & $\begin{array}{c}0.096^{* * *} \\
(0.035)\end{array}$ & $\begin{array}{c}0.033^{* *} \\
(0.016)\end{array}$ & $\begin{array}{c}0.159^{* * *} \\
(0.033)\end{array}$ & $\begin{array}{c}0.044 \\
(0.036)\end{array}$ & $\begin{array}{l}\text { Robust SE: } \\
0.055\end{array}$ \\
\hline Constant & $\begin{array}{c}0.118^{* * *} \\
(0.006)\end{array}$ & $\begin{array}{c}0.440^{* * *} \\
(0.009)\end{array}$ & $\begin{array}{c}0.300^{* * *} \\
(0.008)\end{array}$ & $\begin{array}{c}0.215^{* * *} \\
(0.007)\end{array}$ & $\begin{array}{c}0.546^{* * *} \\
(0.010)\end{array}$ & $\begin{array}{c}0.093^{* * *} \\
(0.005)\end{array}$ & $\begin{array}{c}0.341^{* * *} \\
(0.009)\end{array}$ & $\begin{array}{c}0.426^{* * *} \\
(0.010)\end{array}$ & $\begin{array}{c}\text { P-value: } \\
0.042\end{array}$ \\
\hline $\begin{array}{l}\text { Individual } \\
\text { fixed effects }\end{array}$ & Yes & Yes & Yes & Yes & Yes & Yes & Yes & Yes & \\
\hline Individuals & 1,435 & 1,435 & 1,435 & 1,435 & 1,435 & 1,435 & 1,435 & 1,435 & \\
\hline Observations & 2,870 & 2,870 & 2,870 & 2,870 & 2,870 & 2,870 & 2,870 & 2,870 & \\
\hline R-squared & 0.005 & 0.015 & 0.004 & 0.027 & 0.011 & 0.003 & 0.030 & 0.002 & \\
\hline $\begin{array}{l}\text { Control group mean } \\
\text { in post period }\end{array}$ & 0.146 & 0.530 & 0.274 & 0.144 & 0.609 & 0.109 & 0.472 & 0.446 & \\
\hline
\end{tabular}

Notes: Participants were asked whether they had to cut back their consumption of the particular item due to economic difficulties in the preceding three months. The consumption item variable is a dummy that takes the value of 1 when the answer is yes. Robust standard errors, clustered at the group level, reported in parenthesis. Level of significance: $* * * \mathrm{p}<0.01,{ }^{* *} \mathrm{p}<0.05,{ }^{*} \mathrm{p}<0.10$. 
Table 6: Self-Reported Economic Well-Being

\begin{tabular}{lcccc}
\hline \hline & \multicolumn{2}{c}{ Individual Treatment Effects } & & Average Effect Size (AES) \\
\cline { 2 - 3 } & $\begin{array}{c}\text { Anxiety about } \\
\text { financial future }\end{array}$ & $\begin{array}{c}\text { Recent economic } \\
\text { difficulty }\end{array}$ & & $\begin{array}{c}\text { Subjective } \\
\text { economic well-being }\end{array}$ \\
\hline Account x post & $-0.112^{*}$ & $-0.087^{*}$ & & Coefficient: \\
Post & $(0.059)$ & $(0.051)$ & $-0.102^{* *}$ \\
& $-0.106^{* *}$ & $0.154^{* * *}$ & & Robust SE: \\
Constant & $(0.051)$ & $(0.041)$ & 0.046 \\
& 0.000 & 0.000 & P-value: \\
Individual fixed effects & $(0.013)$ & $(0.012)$ & 0.027 \\
\hline Individuals & Yes & Yes & \\
Observations & 3,519 & 3,515 & \\
R-squared & 7,038 & 7,030 & \\
\hline \hline
\end{tabular}

Notes: Both "anxiety about financial future" and "recent economic difficulty" are expressed in standard deviations. Individuals are excluded in case of non-response to a particular question, which explains the differences in the number of observations. Robust standard errors, clustered at the group level, reported in parenthesis. Level of significance: ${ }^{* * *} \mathrm{p}<0.01,{ }^{* *} \mathrm{p}<0.05,{ }^{*} \mathrm{p}<0.1$. 
Table 7: Take-up of the Account

\begin{tabular}{lc|lcc}
\hline \hline \multirow{2}{*}{ Panel A: Demographics } & $(1)$ & Panel B: Other Characteristics & $(2)$ & $(3)$ \\
& Take-up & Take-up & Take-up \\
\hline Female & $0.079^{* *}$ & Head of household & -0.032 & -0.032 \\
& $(0.039)$ & & $(0.022)$ & $(0.022)$ \\
Age & $0.027^{* * *}$ & Conflict with partner over money & $0.052^{* *}$ & $0.052^{* *}$ \\
& $(0.005)$ & & $(0.024)$ & $(0.024)$ \\
Age squared & $-0.0002^{* * *}$ & Socially taxed & $0.063^{* *}$ & \\
& $(0.0001)$ & & $(0.024)$ & \\
Years of education & 0.005 & Lent to family or friends & & $0.047^{* *}$ \\
& $(0.004)$ & & & $(0.024)$ \\
Children at home & -0.013 & Owes to family or friends & & -0.030 \\
& $(0.009)$ & & & $(0.025)$ \\
Log income & 0.005 & Regret not saving more & 0.006 & 0.006 \\
& $(0.019)$ & & $(0.011)$ & $(0.011)$ \\
Has prior savings account & $0.038^{*}$ & Hyperbolic preferences & $0.052^{* *}$ & $0.052^{* *}$ \\
& $(0.022)$ & & $(0.025)$ & $(0.025)$ \\
& & Fear savings stolen in the home & 0.007 & 0.006 \\
& & & $(0.034)$ & $(0.034)$ \\
Constant & $-0.473^{*}$ & Constant & $-0.483^{*}$ & $-0.475^{*}$ \\
& $(0.281)$ & & $(0.280)$ & $(0.282)$ \\
& & Demographics from panel A & Yes & Yes \\
\hline Individuals & 2,149 & Individuals & 2,052 & 2,052 \\
R-squared & 0.029 & R-squared & 0.041 & 0.040 \\
Mean take-up & 0.389 & Mean take-up & 0.393 & 0.393 \\
\hline \hline
\end{tabular}

Notes: Linear probability regressions among individuals who were offered an account and were present in both surveys, regressing baseline characteristics on take-up. Take-up is defined as actively using the account beyond the minimum opening deposit. The regressions in Panel B include the demographic controls from Panel A. "Children at home" is the total number of individuals aged 18 years or younger living at home. The variable "socially taxed" is a dummy indicating that an individual has lent to family and friends and does not owe to family or friends. Individuals are excluded in case of non-response to a particular question, which explains the lower number of observations in Panel B. Robust standard errors, clustered at the group level, reported in parenthesis. Level of significance: ${ }^{* * *} \mathrm{p}<0.01,{ }^{* *} \mathrm{p}<0.05$, * $\mathrm{p}<0.1$. 
Table 8: Demand Effects

\begin{tabular}{lcc}
\hline \hline & $(1)$ & $(2)$ \\
& $\begin{array}{c}\text { Difficulty of } \\
\text { survey process }\end{array}$ & $\begin{array}{c}\text { Satisfaction } \\
\text { with FE }\end{array}$ \\
\hline Account & 0.040 & -0.014 \\
& $(0.043)$ & $(0.052)$ \\
Constant & $2.45^{* * *}$ & $6.38^{* * *}$ \\
& $(0.033)$ & $(0.042)$ \\
\hline Individuals & 3,366 & 3,573 \\
R-squared & 0.001 & 0.000 \\
\hline \hline
\end{tabular}

Notes: Participants were asked to rate how complicated they found the survey process (scale of 1 to 4 ) and how satisfied they were with Fondo Esperanza (scale of 1 to 7 ). Individuals are excluded in case of non-response to a particular question, which explains the differences in the number of observations. Robust standard errors, clustered at the group level, reported in parenthesis. Level of significance: ${ }^{* * *} \mathrm{p}<0.01,{ }^{* *}$ $\mathrm{p}<0.05,{ }^{*} \mathrm{p}<0.1$. 
Table 9: Differential Effects by Type of Account

\begin{tabular}{lccccc}
\hline \hline & $\begin{array}{c}(1) \\
\text { Short-term } \\
\text { borrowing } \\
\text { amount }\end{array}$ & $\begin{array}{c}\text { (2) } \\
\text { Short-term } \\
\text { borrowing } \\
\text { categories }\end{array}$ & $\begin{array}{c}(3) \\
\text { Anxiety } \\
\text { about } \\
\text { financial } \\
\text { future }\end{array}$ & $\begin{array}{c}(4) \\
\text { Recent } \\
\text { economic } \\
\text { difficulty }\end{array}$ & $\begin{array}{c}\text { Consumption } \\
\text { cutback } \\
\text { categories }\end{array}$ \\
\hline Any account x post & $-9,774$ & $-0.139^{* *}$ & -0.044 & -0.095 & $-0.457^{* *}$ \\
& $(6,975)$ & $(0.063)$ & $(0.068)$ & $(0.061)$ & $(0.215)$ \\
Additional peer group treatment x post & $-5,831$ & 0.022 & $-0.126^{* *}$ & 0.015 & 0.146 \\
& $(6,206)$ & $(0.060)$ & $(0.060)$ & $(0.062)$ & $(0.202)$ \\
Constant & $61,111^{* * *}$ & $0.936^{* * *}$ & 0.000 & 0.000 & $2.479^{* * *}$ \\
& $(1,331)$ & $(0.012)$ & $(0.013)$ & $(0.012)$ & $(0.043)$ \\
R-squared & 0.005 & 0.111 & 0.023 & 0.008 & 0.011 \\
\hline Individual fixed effects & Yes & Yes & Yes & Yes & Yes \\
Year dummy & Yes & Yes & Yes & Yes & Yes \\
Individuals & 3,572 & 3,572 & 3,519 & 3,515 & 1,435 \\
Observations & 7,144 & 7,144 & 7,038 & 7,030 & 2,870 \\
\hline \hline
\end{tabular}

Notes: Regressions for the key results from Tables 3,6 and 5. The first row shows treatment effects for those with just the savings account, the second row shows the difference of the effects for those with the additional peer group support. The outcome variable in Column (5) is the total number of categories of spending a participant had to cut back on and the sample is the same as in Table 5. Individuals are excluded in case of non-response to a particular question, which explains the differences in the number of observations. Robust standard errors, clustered at the group level, in parenthesis. All financial figures are in Chilean pesos. 500 Chilean pesos = about 1 USD. Level of significance: ${ }^{* * *} \mathrm{p}<0.01,{ }^{* *} \mathrm{p}<0.05,{ }^{*} \mathrm{p}<0.1$. 


\section{A Appendix}

Table A1: Effects on Short-Term Borrowing:

Non-Winsorized and Winsorized at the 99th Percentile

\begin{tabular}{|c|c|c|c|c|}
\hline & \multirow[b]{2}{*}{$\begin{array}{c}(1) \\
\text { Total } \\
\text { short-term } \\
\text { borrowing }\end{array}$} & \multicolumn{3}{|c|}{ Components of Short-Term Borrowing } \\
\hline & & $\begin{array}{c}(2) \\
\text { Owed to } \\
\text { family and } \\
\text { friends }\end{array}$ & $\begin{array}{c}(3) \\
\text { Owed to } \\
\text { service } \\
\text { providers }\end{array}$ & $\begin{array}{c}(4) \\
\text { Owed to } \\
\text { business } \\
\text { contacts and } \\
\text { institutions }\end{array}$ \\
\hline \multicolumn{5}{|c|}{ Panel A: Non-Winsorized Amounts } \\
\hline Account $\mathrm{x}$ post & $\begin{array}{c}44,151 \\
(50,172)\end{array}$ & $\begin{array}{c}-3,116 \\
(13,479)\end{array}$ & $\begin{array}{c}42,518 \\
(37,894)\end{array}$ & $\begin{array}{c}4,749 \\
(13,417)\end{array}$ \\
\hline Post & $\begin{array}{l}-73,086 \\
(49,067)\end{array}$ & $\begin{array}{c}-6,108 \\
(12,450)\end{array}$ & $\begin{array}{l}-43,515 \\
(37,665)\end{array}$ & $\begin{array}{c}-23,463^{* *} \\
(11,133)\end{array}$ \\
\hline Constant & $\begin{array}{c}129,840 * * * \\
(9,504)\end{array}$ & $\begin{array}{c}37,943^{* * *} \\
(2,794)\end{array}$ & $\begin{array}{c}39,645^{* * *} \\
(6,960)\end{array}$ & $\begin{array}{c}52,251^{* * *} \\
(3,123)\end{array}$ \\
\hline Control group mean & 98,299 & 43,358 & 21,271 & 33,670 \\
\hline \multicolumn{5}{|c|}{ Panel B: Amounts Winsorized at 99th Percentile } \\
\hline Account $\mathrm{x}$ post & $\begin{array}{c}-9,846 \\
(11,193)\end{array}$ & $\begin{array}{c}-12,129^{*} \\
(6,460)\end{array}$ & $\begin{array}{c}2,000 \\
(2,761)\end{array}$ & $\begin{array}{l}-2,494 \\
(5,491)\end{array}$ \\
\hline Post & $\begin{array}{l}-9,982 \\
(9,529)\end{array}$ & $\begin{array}{c}7,387 \\
(6,019)\end{array}$ & $\begin{array}{l}-2,929 \\
(2,280)\end{array}$ & $\begin{array}{c}-8,689^{*} \\
(4,620)\end{array}$ \\
\hline Constant & $\begin{array}{c}90,784^{* * *} \\
(2,547)\end{array}$ & $\begin{array}{c}25,185^{* * *} \\
(1,323)\end{array}$ & $\begin{array}{c}18,844^{* * *} \\
(646)\end{array}$ & $\begin{array}{c}33,087^{* * *} \\
(1,263)\end{array}$ \\
\hline Control group mean & 89,375 & 36,665 & 16,733 & 25,673 \\
\hline Individual fixed effects & Yes & Yes & Yes & Yes \\
\hline Individuals & 3,572 & 3,572 & 3,572 & 3,572 \\
\hline Observations & 7,144 & 7,144 & 7,144 & 7,144 \\
\hline
\end{tabular}

Notes: Robust standard errors, clustered at the group level, reported in parenthesis. For categories included in each component of short-term borrowing, see Section 2.3. All financial figures are in Chilean pesos. 500 Chilean pesos $=$ about 1 USD. Level of significance: ${ }^{* * *} \mathrm{p}<0.01,{ }^{* *} \mathrm{p}<0.05,{ }^{*} \mathrm{p}<0.1$. 
Table A2: Effects on Lending:

Non-Winsorized and Winsorized at the 99th Percentile

\begin{tabular}{|c|c|c|c|c|c|c|}
\hline & \multicolumn{3}{|c|}{ Full Sample } & \multicolumn{3}{|c|}{ Always or Frequently Regret } \\
\hline & (1) & $(2)$ & $(3)$ & (4) & $(5)$ & (6) \\
\hline & $\begin{array}{c}\text { Total } \\
\text { lending }\end{array}$ & $\begin{array}{l}\text { Lent to } \\
\text { family and } \\
\text { friends }\end{array}$ & $\begin{array}{l}\text { Lent to } \\
\text { business } \\
\text { contacts }\end{array}$ & $\begin{array}{l}\text { Total } \\
\text { lending }\end{array}$ & $\begin{array}{l}\text { Lent to } \\
\text { family and } \\
\text { friends }\end{array}$ & $\begin{array}{l}\text { Lent to } \\
\text { business } \\
\text { contacts }\end{array}$ \\
\hline \multicolumn{7}{|c|}{ Panel A: Non-winsorized Amounts } \\
\hline Account $\mathrm{x}$ post & $\begin{array}{l}-16,744 \\
(31,272)\end{array}$ & $\begin{array}{c}-15,243 \\
(24,408)\end{array}$ & $\begin{array}{c}-1,501 \\
(18,836)\end{array}$ & $\begin{array}{c}-22,676 \\
(41,193)\end{array}$ & $\begin{array}{l}-35,512 \\
(34,777)\end{array}$ & $\begin{array}{c}12,836 \\
(19,753)\end{array}$ \\
\hline Post & $\begin{array}{c}-873 \\
(17,532)\end{array}$ & $\begin{array}{c}-846 \\
(10,922)\end{array}$ & $\begin{array}{c}-27 \\
(13,120)\end{array}$ & $\begin{array}{c}8,332 \\
(25,177)\end{array}$ & $\begin{array}{c}13,644 \\
(14,807)\end{array}$ & $\begin{array}{c}-5,312 \\
(19,051)\end{array}$ \\
\hline Constant & $\begin{array}{c}133,705^{* * *} \\
(8,833)\end{array}$ & $\begin{array}{c}73,474^{* * *} \\
(7,221)\end{array}$ & $\begin{array}{c}60,231 * * * \\
(4,917)\end{array}$ & $\begin{array}{c}133,858^{* * *} \\
(11,400)\end{array}$ & $\begin{array}{c}81,480 * * * \\
(10,448)\end{array}$ & $\begin{array}{c}52,378^{* * *} \\
(3,797)\end{array}$ \\
\hline Control group mean & 115,477 & 56,401 & 59,076 & 129,630 & 66,675 & 62,954 \\
\hline \multicolumn{7}{|c|}{ Panel B: Amounts Winsorized at 99th Percentile } \\
\hline Account $\mathrm{x}$ post & $\begin{array}{c}-58 \\
(9,766)\end{array}$ & $\begin{array}{l}-4,203 \\
(6,497)\end{array}$ & $\begin{array}{c}4,080 \\
(4,521)\end{array}$ & $\begin{array}{c}-18,804^{*} \\
(11,123)\end{array}$ & $\begin{array}{c}-15,774^{* *} \\
(7,988)\end{array}$ & $\begin{array}{c}1,195 \\
(5,108)\end{array}$ \\
\hline Post & $\begin{array}{l}10,675 \\
(7,707)\end{array}$ & $\begin{array}{l}-1,423 \\
(5,075)\end{array}$ & $\begin{array}{c}8,421^{* *} \\
(3,362)\end{array}$ & $\begin{array}{c}23,458^{* * *} \\
(8,775)\end{array}$ & $\begin{array}{c}8,472 \\
(6,255)\end{array}$ & $\begin{array}{l}7,624^{*} \\
(3,890)\end{array}$ \\
\hline Constant & $\begin{array}{c}96,449 * * * \\
(2,371)\end{array}$ & $\begin{array}{c}52,107^{* * *} \\
(1,587)\end{array}$ & $\begin{array}{c}39,331^{* * *} \\
(1,139)\end{array}$ & $\begin{array}{c}97,055^{* * *} \\
(2,704)\end{array}$ & $\begin{array}{c}54,242^{* * * *} \\
(1,949)\end{array}$ & $\begin{array}{c}39,380^{* * *} \\
(1,271)\end{array}$ \\
\hline Control group mean & 101,133 & 45,143 & 48,396 & 108,888 & 51,071 & 49,157 \\
\hline Individual fixed effects & Yes & Yes & Yes & Yes & Yes & Yes \\
\hline Individuals & 3,566 & 3,566 & 3,566 & 2,438 & 2,438 & 2,438 \\
\hline Observations & 7,132 & 7,132 & 7,132 & 4,876 & 4,876 & 4,876 \\
\hline
\end{tabular}

Notes: Participants were asked if they regretted not having saved more in the preceding three months. Columns (4)-(6) contain the sample of participants who indicated that they 'always' or 'frequently' regretted not having saved more. Robust standard errors, clustered at the group level, reported in parenthesis. All financial figures are in Chilean pesos. 500 Chilean pesos $=$ about 1 USD. Level of significance: ${ }^{* * *} \mathrm{p}<0.01$, ** $\mathrm{p}<0.05,{ }^{*} \mathrm{p}<0.10$. 
Table A3: Consumption Variation (Entire Sample)

\begin{tabular}{|c|c|c|c|c|c|c|c|c|c|}
\hline & \multicolumn{8}{|c|}{ Individual Treatment Effects } & \multirow{3}{*}{$\begin{array}{c}\text { AES } \\
(9) \\
\text { Consumption } \\
\text { variation } \\
(\text { Cols } 1-8)\end{array}$} \\
\hline & (1) & $(2)$ & (3) & $(4)$ & $(5)$ & (6) & $(7)$ & $(8)$ & \\
\hline & Meals & Meat & Medicines & $\begin{array}{c}\text { School } \\
\text { supplies }\end{array}$ & Clothing & $\begin{array}{l}\text { School } \\
\text { snacks }\end{array}$ & $\begin{array}{l}\text { Public } \\
\text { transport }\end{array}$ & $\begin{array}{c}\text { Eating } \\
\text { out }\end{array}$ & \\
\hline Account $\mathrm{x}$ post & $\begin{array}{l}-0.013 \\
(0.016)\end{array}$ & $\begin{array}{l}-0.047^{*} \\
(0.027)\end{array}$ & $\begin{array}{l}-0.024 \\
(0.022)\end{array}$ & $\begin{array}{l}-0.008 \\
(0.018)\end{array}$ & $\begin{array}{c}0.006 \\
(0.032)\end{array}$ & $\begin{array}{l}-0.004 \\
(0.013)\end{array}$ & $\begin{array}{l}-0.050^{*} \\
(0.028)\end{array}$ & $\begin{array}{l}-0.021 \\
(0.030)\end{array}$ & $\begin{array}{l}\text { Coefficient: } \\
-0.046\end{array}$ \\
\hline Post & $\begin{array}{c}0.005 \\
(0.013)\end{array}$ & $\begin{array}{c}0.022 \\
(0.022)\end{array}$ & $\begin{array}{c}-0.039^{* *} \\
(0.018)\end{array}$ & $\begin{array}{c}-0.092^{* * *} \\
(0.014)\end{array}$ & $\begin{array}{l}-0.029 \\
(0.027)\end{array}$ & $\begin{array}{l}-0.008 \\
(0.010)\end{array}$ & $\begin{array}{l}0.061^{* *} \\
(0.023)\end{array}$ & $\begin{array}{l}-0.022 \\
(0.026)\end{array}$ & $\begin{array}{l}\text { Robust SE: } \\
0.038\end{array}$ \\
\hline Constant & $\begin{array}{c}0.107^{* * *} \\
(0.004)\end{array}$ & $\begin{array}{c}0.408^{* * *} \\
(0.006)\end{array}$ & $\begin{array}{c}0.263^{* * *} \\
(0.005)\end{array}$ & $\begin{array}{c}0.202^{* * *} \\
(0.004)\end{array}$ & $\begin{array}{c}0.513^{* * *} \\
(0.007)\end{array}$ & $\begin{array}{c}0.085^{* * *} \\
(0.003)\end{array}$ & $\begin{array}{c}0.317^{* * *} \\
(0.007)\end{array}$ & $\begin{array}{c}0.416^{* * *} \\
(0.007)\end{array}$ & $\begin{array}{l}\text { P-value: } \\
0.229\end{array}$ \\
\hline $\begin{array}{l}\text { Individual } \\
\text { fixed effects }\end{array}$ & Yes & Yes & Yes & Yes & Yes & Yes & Yes & Yes & \\
\hline Individuals & 3,583 & 3,583 & 3,583 & 3,583 & 3,583 & 3,583 & 3,583 & 3,583 & \\
\hline Observations & 7,166 & 7,166 & 7,166 & 7,166 & 7,166 & 7,166 & 7,166 & 7,166 & \\
\hline R-squared & 0.001 & 0.002 & 0.011 & 0.043 & 0.002 & 0.001 & 0.004 & 0.003 & \\
\hline $\begin{array}{l}\text { Control group mean } \\
\text { in post period }\end{array}$ & 0.109 & 0.409 & 0.212 & 0.107 & 0.482 & 0.072 & 0.365 & 0.380 & \\
\hline
\end{tabular}

Notes: Participants were asked whether they had to cut back their consumption of the particular item due to economic difficulties in the preceding three months. The consumption item variable is a dummy that takes the value of 1 when the answer is yes. Robust standard errors, clustered at the group level, reported in parenthesis. Level of significance: $* * * \mathrm{p}<0.01,{ }^{* *} \mathrm{p}<0.05,{ }^{*} \mathrm{p}<0.10$. 


\section{Generalized Ordered Probit}

Table A4: Anxiety about the Financial Future

\begin{tabular}{lccc}
\hline \hline & $(1)$ & $(2)$ & $(3)$ \\
& Anxiety $>1$ & Anxiety $>2$ & Anxiety $>3$ \\
\hline Account x post & -0.067 & -0.093 & $-0.177^{* *}$ \\
Account & $(0.106)$ & $(0.077)$ & $(0.080)$ \\
Post & 0.040 & -0.007 & 0.084 \\
& $(0.068)$ & $(0.062)$ & $(0.057)$ \\
Constant & 0.062 & $-0.224^{* * *}$ & -0.100 \\
& $(0.088)$ & $(0.067)$ & $(0.064)$ \\
Observations & $1.191^{* * *}$ & $0.576^{* * *}$ & $-0.496^{* * *}$ \\
\hline \hline
\end{tabular}

Notes: The dependent variable in each Column is "anxiety about financial future" taking a value of 0 or 1 , depending on the threshold in question. In Column (1), "anxiety" takes a value of 1 if anxiety is rated above ' 1 ' and zero otherwise. In Column (2), "anxiety" takes a value of 1 if it is rated above ' 2 ' and zero otherwise, etc. Robust standard errors, clustered at the group level, reported in parenthesis. Level of significance: ${ }^{* * *} \mathrm{p}<0.01,{ }^{* *} \mathrm{p}<0.05,{ }^{*}$ $\mathrm{p}<0.1$. 
Table A5: Recent Economic Difficulty

\begin{tabular}{lcccc}
\hline \hline & $\begin{array}{c}(1) \\
\text { Economic } \\
\text { difficulty }>2\end{array}$ & $\begin{array}{c}(2) \\
\text { Economic } \\
\text { difficulty }>4\end{array}$ & $\begin{array}{c}(3) \\
\text { Economic } \\
\text { difficulty }>6\end{array}$ & $\begin{array}{c}(4) \\
\text { Economic } \\
\text { difficulty }>8\end{array}$ \\
\hline Account x post & -0.079 & $-0.150^{* *}$ & -0.077 & -0.052 \\
& $(0.078)$ & $(0.069)$ & $(0.071)$ & $(0.077)$ \\
Account & 0.077 & 0.088 & 0.074 & 0.072 \\
Post & $(0.058)$ & $(0.056)$ & $(0.057)$ & $(0.062)$ \\
& $0.358^{* * *}$ & $0.262^{* * *}$ & 0.082 & -0.015 \\
Constant & $(0.061)$ & $(0.053)$ & $(0.060)$ & $(0.058)$ \\
& $0.752^{* * *}$ & $0.218^{* * *}$ & $-0.578^{* * *}$ & $-1.121^{* * *}$ \\
\hline Observations & $(0.046)$ & $(0.044)$ & 0.046 & $(0.049)$ \\
\hline \hline
\end{tabular}

Notes: The dependent variable "recent economic difficulty" ranges from 1 to 10 . For this regression it has been aggregated into bins of two. In Column (1), "past economic difficulty" takes a value of 1 if past economic difficulty is rated above ' 2 ' and zero otherwise. In Column (2), "past economic difficulty" takes a value of 1 if it is rated above ' 4 ' and zero otherwise, etc. Robust standard errors, clustered at the group level, reported in parenthesis. Level of significance: ${ }^{* * *} \mathrm{p}<0.01,{ }^{* *} \mathrm{p}<0.05,{ }^{*} \mathrm{p}<0.1$. 


\section{Attrition}

Table A6: Balance of Attrition

\begin{tabular}{|c|c|c|c|c|}
\hline & $\begin{array}{c}1) \\
\text { Control } \\
\text { means }\end{array}$ & $\begin{array}{c}(2) \\
\text { Difference: } \\
\text { treatment - control }\end{array}$ & $\begin{array}{c}(3) \\
\text { Non-attritors } \\
\text { means }\end{array}$ & $\begin{array}{c}(4) \\
\text { Difference: } \\
\text { attritors - non-attritors }\end{array}$ \\
\hline Attrition & $\begin{array}{c}0.12 \\
(0.33)\end{array}$ & $\begin{array}{l}0.03^{* *} \\
(0.01)\end{array}$ & & \\
\hline Age & & & $\begin{array}{c}43.52 \\
(11.58)\end{array}$ & $\begin{array}{c}-1.18^{* *} \\
(0.50)\end{array}$ \\
\hline Years of education & & & $\begin{array}{c}9.68 \\
(3.08)\end{array}$ & $\begin{array}{c}0.21 \\
(0.14)\end{array}$ \\
\hline Household size & & & $\begin{array}{c}4.33 \\
(1.73)\end{array}$ & $\begin{array}{c}-0.16^{* *} \\
(0.08)\end{array}$ \\
\hline $\begin{array}{l}\text { Per capita monthly household } \\
\text { income }\end{array}$ & & & $\begin{array}{c}80,034 \\
(62,091)\end{array}$ & $\begin{array}{l}2,025 \\
(2,492)\end{array}$ \\
\hline Has prior savings account & & & $\begin{array}{c}0.33 \\
(0.47)\end{array}$ & $\begin{array}{l}-0.00 \\
(0.02)\end{array}$ \\
\hline Prior formal savings amount & & & $\begin{array}{c}62,306 \\
(232,150)\end{array}$ & $\begin{array}{l}32,687^{*} \\
(18,416)\end{array}$ \\
\hline Short-term borrowing amount & & & $\begin{array}{c}129,852 \\
(1,111,991)\end{array}$ & $\begin{array}{l}-22,767 \\
(25,813)\end{array}$ \\
\hline $\begin{array}{l}\text { Short-term borrowing amount } \\
\text { winsorized at } 95 \%\end{array}$ & & & $\begin{array}{c}63,701 \\
(129,018)\end{array}$ & $\begin{array}{l}-2,910 \\
(5,862)\end{array}$ \\
\hline Short-term borrowing categories & & & $\begin{array}{c}0.94 \\
(1.16)\end{array}$ & $\begin{array}{l}-0.06 \\
(0.05)\end{array}$ \\
\hline Short-term lending amount & & & $\begin{array}{c}133,747 \\
(1,047,081)\end{array}$ & $\begin{array}{c}-39,117^{* *} \\
(19,440)\end{array}$ \\
\hline $\begin{array}{l}\text { Short-term lending amount } \\
\text { winsorized at } 95 \%\end{array}$ & & & $\begin{array}{c}72,480 \\
(120,306)\end{array}$ & $\begin{array}{c}2,170 \\
(5,296)\end{array}$ \\
\hline Short-term lending categories & & & $\begin{array}{c}1.11 \\
(1.22)\end{array}$ & $\begin{array}{l}-0.01 \\
(0.05)\end{array}$ \\
\hline Need to cut back consumption & & & $\begin{array}{c}0.71 \\
(0.45)\end{array}$ & $\begin{array}{l}-0.02 \\
(0.02)\end{array}$ \\
\hline Anxious about financial future & & & $\begin{array}{c}2.93 \\
(0.97)\end{array}$ & $\begin{array}{l}-0.05 \\
(0.05)\end{array}$ \\
\hline Recent economic difficulty & & & $\begin{array}{c}5.12 \\
(2.77)\end{array}$ & $\begin{array}{c}0.02 \\
(0.12)\end{array}$ \\
\hline Individuals & 1,488 & 2,687 & 3,583 & 592 \\
\hline
\end{tabular}

Notes: Columns (1) and (2) show the regression of attrition on the treatment dummy and a constant term for the full sample. Columns (3) and (4) show the coefficients from the regressions of the pre-treatment variable in question on the attrition dummy and a constant term. Columns (1) and (3) report standard deviation in the parenthesis, whereas Columns (2) and (4) report standard errors from the respective regression in parenthesis. The variables "anxious about financial future" and "recent economic difficulty" range from 1 to 4 and 1 to 10 respectively. All financial figures in Chilean pesos. 500 Chilean pesos $=$ about 1 USD. Level of significance: ${ }^{* * *} \mathrm{p}<0.01,{ }^{* *} \mathrm{p}<0.05,{ }^{*} \mathrm{p}<0.1$. 
Table A7: Lee Bounds

\begin{tabular}{lcccc}
\hline \hline & $\begin{array}{c}(1) \\
\text { Short-term } \\
\text { borrowing } \\
\text { amount }\end{array}$ & $\begin{array}{c}\text { Short-term } \\
\text { borrowing } \\
\text { categories }\end{array}$ & $\begin{array}{c}(3) \\
\text { Anxiety } \\
\text { about } \\
\text { financial } \\
\text { future }\end{array}$ & $\begin{array}{c}(4) \\
\text { Recent } \\
\text { economic } \\
\text { difficulty }\end{array}$ \\
\hline Point estimate & $-12,931^{* *}$ & $0.127^{* *}$ & $-0.112^{*}$ & $-0.087^{*}$ \\
Lower bound & {$[-13,839$,} & {$[-0.138$,} & {$[-0.170$,} & {$[-0.123$,} \\
Upper bound & $-3,140]$ & $-0.076]$ & $-0.080]$ & $-0.056]$ \\
\hline Individuals after trimming & 3,572 & 3,572 & 3,478 & 3,475 \\
Observations after trimming & 7,144 & 7,144 & 6,956 & 6,950 \\
\hline \hline
\end{tabular}

Notes: Lee bounds for the main results from Tables 3 and 6, calculated using the methodology discussed in Section 3.3. Rows 2 and 3 show the Lee bounds. The bounds cannot be calculated for the improvements in consumption smoothing in case of economic shocks (Table 5), since by construction, we do not know, which attritors had shocks. The first row shows the point estimates from the original regression. All financial figures are in Chilean pesos. 500 Chilean pesos $=$ about 1 USD. Level of significance: ${ }^{* * *} \mathrm{p}<0.01,{ }^{* *} \mathrm{p}<0.05,{ }^{*} \mathrm{p}<0.1$. 
Table A8: Inverse Probability Weighting

\begin{tabular}{lccccc}
\hline \hline & $\begin{array}{c}(1) \\
\text { Total } \\
\text { short-term } \\
\text { borrowing } \\
\text { amount }\end{array}$ & $\begin{array}{c}\text { Total } \\
\text { short-term } \\
\text { borrowing } \\
\text { categories }\end{array}$ & $\begin{array}{c}\text { Anxiety } \\
\text { about } \\
\text { financial } \\
\text { future }\end{array}$ & $\begin{array}{c}(4) \\
\text { Recent } \\
\text { economic } \\
\text { difficulty }\end{array}$ & $\begin{array}{c}\text { Consumption } \\
\text { cutback } \\
\text { categories }\end{array}$ \\
\hline Account x post & $-13,930^{* *}$ & $-0.127^{* *}$ & $-0.117^{*}$ & $-0.096^{*}$ & $-0.396^{* *}$ \\
& $(5,847)$ & $(0.051)$ & $(0.060)$ & $(0.051)$ & $(0.188)$ \\
Post & 576 & $-0.334^{* * *}$ & $-0.097^{*}$ & $0.157^{* * *}$ & $0.417^{* * *}$ \\
& $(4,977)$ & $(0.042)$ & $(0.051)$ & $(0.041)$ & $(0.157)$ \\
Constant & $60,939^{* * *}$ & $0.927^{* * *}$ & -0.008 & 0.002 & $2.483^{* * *}$ \\
& $(1,339)$ & $(0.012)$ & $(0.013)$ & $(0.012)$ & $(0.043)$ \\
Individual & & & & & \\
fixed effects & Yes & Yes & Yes & Yes & Yes \\
R-squared & 0.006 & 0.109 & 0.021 & 0.008 & 0.011 \\
Individuals & 3,572 & 3,572 & 3,519 & 3,515 & 1,435 \\
Observations & 7,144 & 7,144 & 7,038 & 7,030 & 2,870 \\
\hline \hline
\end{tabular}

Notes: Regressions for the key results from Tables 3, 6 and 5, weighted using the inverse probability weights described in Section 3.3. The outcome variable in Column (5) is the total number of categories of spending a participant had to cut back on and the sample is the same as in Table 5. All financial figures are in Chilean pesos. 500 Chilean pesos $=$ about 1 USD. Robust standard errors, clustered at the group level, in parentheses. Level of significance: ${ }^{* * *} \mathrm{p}<0.01,{ }^{* *} \mathrm{p}<0.05,{ }^{*} \mathrm{p}<0.10$. 